Article

\title{
Islam in Australia: A National Survey of Muslim Australian Citizens and Permanent Residents
}

\author{
Halim Rane ${ }^{1, *} \mathbb{0}$, Adis Duderija ${ }^{2}$, Riyad H. Rahimullah ${ }^{3}$, Paul Mitchell ${ }^{1}$, Jessica Mamone ${ }^{1}$ and \\ Shane Satterley ${ }^{2}$ (D) \\ 1 Centre for Social and Cultural Research, Griffith University, Nathan, QLD 4111, Australia; \\ paul.mitchell@griffith.edu.au (P.M.); j.mamone@griffith.edu.au (J.M.) \\ 2 School of Humanities, Languages and Social Science, Griffith University, Nathan, QLD 4111, Australia; \\ a.duderija@griffith.edu.au (A.D.); shane.satterley@griffithuni.edu.au (S.S.) \\ 3 School of Human Services and Social Work, Griffith University, Nathan, QLD 4111, Australia; \\ riyad.rahimullah@gmail.com \\ * Correspondence: h.rane@griffith.edu.au
}

Received: 27 July 2020; Accepted: 11 August 2020; Published: 14 August 2020

\begin{abstract}
This article presents the findings of a national survey on Islam in Australia based on responses of 1034 Muslim Australian citizens and permanent residents. Knowing what Muslim Australians think about Islam in relation to Australian society is essential for a more informed understanding about Islam and Muslims needed to address misinformation, Islamophobia, and extremism. The findings presented in this article include typologies of Muslims; sources of influence concerning Islam; interpretations of the Qur'an; perspectives on ethical, social, and theological issues; issues of concern; social connections and sense of belonging; views on various Muslim-majority countries; and perspectives concerning political Islam, including jihad, caliphate, and shariah. While respondents' understandings, interpretations, and expressions of Islam overall align with values and principles of equality, human rights, social cohesion, and social justice, a minority were found to understand and interpret Islam in ways that reflect the influence of late 20th and early 21st century ideas associated with Islamist political ideology, and a smaller sub-group were found to have views that could be considered extreme. This article discusses these findings in relation to the early 21st century time-period factors and the Australian social context.
\end{abstract}

Keywords: Islam; Muslims; Australia; online survey; national security; social cohesion

\section{Introduction}

In the aftermath of the terrorist attacks in the United States on 11 September 2001 and the 'War on Terror', Islam and Muslims have been a constant focus of media, political and public attention. The faith and its adherents have been routinely framed within the context of conflict, violence, and terrorism (Rane et al. 2014). In more recent years, social media has become a critical space where, as articulated by one study, "posts stoke deep hatred of Islam across the western world and influence politics in Australia, Canada, UK and US" by blending "distorted news and total fabrication to paint Muslims as sharia-imposing terrorists ... whose existence poses a threat to white culture and western civilization" (Knaus et al. 2019). Given that Muslims are among the largest non-Christian religious groups in Australia, that over 60 percent of the world's Muslim population resides in the South/South East Asian region, and that Islam is predicted to have more followers than any other religion by the latter half of this century (Pew Research Center 2015), a better understanding of Islam and Muslims in Australia is essential.

In Australia, a number of factors have contributed to a perception that Islam and Muslims threaten peace and security, including: (i) Australia's National Terrorism Threat Level assessment 
that identifies the most likely perpetrators as Islamist extremists (Australian National Security 2019); (ii) identification of approximately 150 Muslim Australians joining the ranks of ISIS (Jenkins 2014) in addition to many others whose passports were cancelled for attempting to do so; (iii) the conviction of dozens of Muslim Australians for terrorism offenses (Rane 2019); and (iv) countering violent extremism policy that officially "reinforces many of the core stereotypes of Islam in the West: militancy, fanaticism, intolerance, fundamentalism, misogyny and alienness" (Dunn et al. 2016, p. 282). These factors highlight the need for a more informed understanding about Islam and Muslims in Australia in order to alleviate unwarranted fears and misconceptions, counter stereotypes and misinformation, and identify issues that require further attention and education.

This article presents the findings of a national survey concerning how Muslim Australians understand, interpret, and express Islam as well as their views on various ethical, social, political, and theological issues. The Islam in Australia survey was fielded online in September and October 2019 and was completed by 1034 Muslim Australian citizens and permanent residents. This article begins by providing a background on Islam and Muslims in Australia, including a brief history of settlement, basic demographics, and contemporary issues relating to national security and social cohesion. It then discusses the methodology of the study, design and fielding of the survey, as well as the focus groups that were subsequently conducted with Muslim community representatives. The findings are then presented in relation to: Respondents' demographics and representativeness; typologies of Muslims; sources of influence concerning Islam; interpretations of the Qur'an; perspectives on ethical, social, and theological issues; issues of concern; social connections and sense of belonging; views on various Muslim-majority countries; and perspectives concerning political Islam, including jihad, caliphate, and shariah. These findings are then discussed in relation to the early 21 st century time-period and Australian social context, followed by the article's conclusion.

\section{Background}

Muslims have a long history in Australia. Macassan fishermen from Indonesia are known to have made seasonal expeditions to Australia and traded with Indigenous peoples more than a century before European settlement (Ganter 2008). In the 1800s, the earliest Muslims to settle in Australia included Afghans and Indians who worked as cameleers, farmers, and hawkers, and Malays who worked in the pearl industry, followed by Albanians in the 1920s who made their living in agriculture (Jones 1993). The population of Muslims in Australia increased from 2704 in 1947 to 22,311 in 1971 with the repeal of the Immigration Restriction Act in the late 1960s and the transition to multiculturalism as official policy. Australia's Muslim population experienced an almost 10-fold increase between the early 1970s and mid-1990s when it first exceeded 200,000 people. Between 1986 and 1991, Australia's Muslim population experienced a growth rate of 35 percent primarily due to immigration. During this period, nearly 100,000 Muslims arrived in Australia, mostly from the Middle East (Bouma 1995). This was followed by a further doubling of the Muslim population by 2011. According to the 2016 census, there are 604,200 Muslim Australians (2.6\% of total population of approximately 23.4 million $^{1}$ ). Almost 40 percent are Australian-born and of the approximately 60 percent born overseas, most are from Afghanistan, Bangladesh, India, Indonesia, Iran, Iraq, Lebanon, Pakistan, and Turkey, while significant numbers of Muslims have also migrated from Bosnia, Egypt, Fiji, Malaysia, Somalia, and over 150 other countries (Hassan 2015). This mix makes Australia's Muslims highly diverse in terms of ethnicities, cultures, and languages as well as in relation to lived experiences concerning Islam.

The survey's findings capture a time-period, some 1400-hundred years in duration, and a world away from the context of 7th-century Arabia, in which the Qur'an was revealed to the Prophet Muhammad (d. 632). This time-period also encompasses the centuries that followed, when Islam

1 Figure of 23.4 million reflects the findings of the 2016 census. At the time of writing, the total population of Australia was estimated at approximately 25.6 million. 
flourished as a civilization. During this time, Islamic civilization developed social and political structures and institutions as well as theology, philosophy and jurisprudence that influenced what Muslims and non-Muslims today think about Islam. Additionally, we must also consider that the time-period of this survey is marked by the context of European colonization of the Muslim world, post-colonization experiences of modern Muslim nation-states, the emergence of conservative and politicized forms of Islam, increased securitization in relation to Islam and Muslims, and the rise of strong anti-Islam/anti-Muslim sentiments.

With the exception of the four respondents who identified as Aboriginal, the survey respondents are all immigrants or descendants of migrants. This includes those whose family migrated from Europe, as is the case for many converts to Islam, as well as respondents from Muslim-majority nation-states, most of which have been independent for less than a century. Since the latter half of the 20th century, Islam has been interpreted and utilized in response to social, political, and other challenges that have shaped how many Muslims understand the religion. The survey respondents' understandings, interpretations, and expressions must be recognized in relation to such factors as an early 21st century manifestation of Islam that will continue to evolve.

While Muslim communities have been established and peacefully coexisted in Australia for well over a century (Bouma 1994; Duderija and Rane 2019), it was not until the turn of the 21st century that a number of phenomena emerged in relation to Islam and Muslims that have threatened national security and social cohesion. As alluded to above, the past two decades have seen a marked increase in anti-Islam/anti-Muslim sentiments, which various studies and polls have found are harbored by 25 to 50 percent of the Australian population (Markus 2018; Essential Research 2016; Dunn et al. 2007). Moreover, during this time-period, Islamophobia ${ }^{2}$ has been on the rise (Iner 2019; Hassan and Martin 2015) and, for the first time in Australia's history, multiple social movements and political parties have emerged with explicit anti-Islam agendas (Dean et al. 2016). These developments are, in part, a response to the spread and fear of Islamist-jihadist ideology that has seen 47 Muslim Australian men imprisoned for terrorism offences over the past 15 years (Rane 2019). Justice Desmond Fagan highlights that "in all of these cases the 'cause' underlying the offence, although described by the courts in a variety of ways, has been that of furthering Islamic ideology by force and fear through indiscriminate killing of non-Muslims" (Rane 2019, p. 4).

A central aspect of the time-period of this survey is that over the past two decades, a perception of Islam as a violent, existential threat to non-Muslims has impacted the lived experiences of Muslim Australians. Since the latter half of the 20th century, the notion of an Islamic threat in relation to political Islam has been building (Esposito 1999) as Islamism and Wahhabism have been promoted quite aggressively by their proponents as authentic and true Islam in both Muslim-majority countries and the West. In the context of Southeast Asia, for instance, Means (2009, p. 4) describes the changes to Islam in Malaysia and Indonesia that occurred in the 1970s and 1980s in relation to "the massive campaign mounted by Saudi Arabia to propagate and promote the religious and doctrinal principles of Sunni Islam as practiced in Arabia", noting that "what was conservative for Saudi Arabia became a radical message for Southeast Asia's moderate and eclectic Muslim communities" (2009, p. 5). As Muslim-majority countries such as Saudi Arabia and Iran competed for authority and leadership vis-à-vis the global Muslim ummah (community), Western countries also became an important battle ground. Laurence (2012, p. 54) describes the scales and influence of Saudi Arabia in the process of spreading its form of Islam in the West, noting that "the boom in Saudi proselytism around the world-through the construction of grand mosques, the circulation of millions of free Wahhabi prayer books, and the dispatching of missionaries and imams - was funded by petrodollars at an estimated expense of more than $\$ 85$ billion between 1975 and 2005, reflecting a determined effort

2 As noted by Duderija and Rane (2019) in their chapter on "Islamophobia", while there is no single agreed-upon definition of the term, it is generally understood in reference to fear, prejudice and/or discrimination of/against Islam and/or Muslims and can manifest in various forms including verbal and physical abuse, hate crimes and social exclusion. 
to establish spiritual and political hegemony over Muslim practice". Other studies have identified changes to early Islam and experiences of early Muslim communities in the West after the 1970s. Howell (2014) contends that an American Islam had developed by the 1950s but the continuity of this phenomenon was limited in later decades by new Muslim migrants who imposed alternate perspectives of Islam and helped alter the place of Muslims in American society.

Particularly since the 1970s, Muslim Australians sought funding for mosques from foreign Muslim governments, including Libya, Iran, Iraq, Saudi Arabia, Turkey, and UAE. Humphrey (2001, p. 39) notes this funding reflects competition between Muslim states for "global Islamic leadership and patronage in maintaining the Islamic faith of all Believers" as well as "continued influence of Islamic political parties and movements in the diaspora". In part, external influences laid a foundation for Islamist jihadists to exploit in the 21st century, particularly as grievances grew in response to the death and destruction caused by Western military interventions. As anticipated by the UK Joint Intelligence Committee prior to the 2003 invasion of Iraq, the Islamist threat would be heightened and anti-Western sentiment within Western Muslim communities would intensify in the event of war (Chilcot 2016).

Currently, Australia's National Terrorism Threat Level is 'probable', with terrorism considered most likely to be perpetrated by "a small number of Islamist extremists" (Australian National Security 2019), while the threat posed by far-right extremists is also present and increasing (ASIO 2020). Brenton Tarrant, the convicted Australian terrorist who killed 51 Muslims at mosques in Christchurch, New Zealand in 2019, wrote a manifesto depicting Islam as violent and intolerant of non-Muslims, who are in danger of a 'great replacement' by Muslim immigrants. His inspiration, Anders Breivik, who killed 77 people in Norway in 2011, depicted the history of Islam in his 1516-page manifesto as a 'jihad' against peoples of other faiths (Berwick 2011). While the concept of jihad been addressed elsewhere (Al-Dawoody 2011; Rane 2009), far-right and Islamist-jihadist narratives have certainly contributed to the insecurity of communities and provided justification for the securitization of society. It should also be noted that, in addition to terrorism concerns, demography has also been identified as a key driver in relation to fear of Islam and/or Muslims, often expressed as a demographic threat or fear of Muslim population growth (Larsson 2012; Essential Research 2016), including a 'great replacement' of non-Muslims by Muslim immigrants (Berwick 2011). Against this background, the Islam in Australia survey findings provide insights on what Muslim Australians actually think about Islam in relation to Australian society, which is essential for a more informed understanding about Islam and Muslims in Australia.

\section{Methodology}

Over the past two decades, a number of surveys have been conducted to capture the views and opinions of Muslims in the West, including in North America, Europe, and Australia. They have examined religious identity and beliefs, views on political and social issues, as well as experiences of racism, Islamophobia, and integration. Examples of these include multiple national surveys of Muslim Americans conducted by the Pew Research Center $(2007,2011,2017)$, which have provided in-depth examinations of various religious, social, and political issues. The Institute for Social Policy and Understanding (ISPU) also conducts polls of Muslim Americans on issues including social relations, racism, and Islamophobia (Mogahed and Mahmood 2019). Perhaps one of the largest studies conducted was the Gallup World Poll, which included tens of thousands of interviews with Muslims in 35 countries with predominantly Muslim populations, as well as Muslim Americans, to gain insight into what Muslims really think about such issues as democracy, radicalism, gender, and Islam-West relations (Esposito and Mogahed 2007). Another study conducted in 2010 in Denmark focused specifically on Muslim youth radicalization and integration (Goli and Rezaei 2011), while a 2016 survey of Canadian Muslims examined religious belief and identity, discrimination and belonging, as well as community and social issues (The Environics Institute for Survey Research 2016). In the Australian context, there have been a number of attempts to survey Muslim Australians, including their views on religion, social issues, identity, and integration. For instance, Rane et al. (2011) conducted a survey of Muslims 
in Queensland, which examined participant views on a range of issues including identity and social integration. Dunn et al. (2016) conducted a survey of Muslims in Sydney, which examined participants' views on diversity, equality, and integration. Methodologically, these surveys have primarily been conducted via telephone (Goli and Rezaei 2011), self-administered questionnaires (Rane et al. 2011), face-to-face interviews (Pew Research Center), and a combination of both telephone and face-to-face (Dunn et al. 2016). However, the internet and social media have increasingly been recognized as effective platforms for conducting surveys, particularly for minority groups and diverse communities whose members may be hard to reach in order to capture a representative sample (Johnson et al. 2016).

The Islam in Australia survey was conducted through the Centre for Social and Cultural Research, Griffith University in Australia. It was fielded online and focused specifically on how Muslim Australians understand, interpret, and express Islam as part of their lived experience. The survey was designed in relation to questions arising from the academic literature concerning Islam in the contemporary world, particularly Muslims in the West. It consisted of over 150 questions, including two preliminary eligibility questions, 13 demographic questions, approximately 20 convert-specific questions, and approximately 130 main questions. Depending on responses to certain questions, respondents may have been asked more or fewer questions. ${ }^{3}$ The questionnaire used predominantly Likert scales to measure respondents' agreement/disagreement and concern in relation to various statements, as well as several open-ended questions. Most respondents required 30-40 min to complete the survey. The survey was conducted according to the ethical standards required by Griffith University ${ }^{4}$ and in close consultation with Muslim Australian religious authorities, community leaders and representatives of various Muslim organizations. Early drafts of the survey instrument were pilot tested with Muslim community representatives in Queensland, refined, and shared with Muslim community representatives in other states for feedback.

The survey instrument was finalized and fielded online using Lime Survey. The survey was conducted in English only ${ }^{5}$ and disseminated online with the support of Muslim community organizations, groups, and individuals around Australia who shared the link to the survey through email and across social media platforms, particularly Facebook. Online surveys are effective and efficient for studying minority communities, especially those that may be difficult to recruit (Johnson et al. 2016) as in the case of Muslim Australians who are a small percentage of the Australian population. Utilizing the support of Muslim community organizations, groups, and individuals to disseminate the survey resulted in wide distribution and penetration into diverse communities and groupings of Muslims. The survey was open to all Muslim Australian citizens and permanent residents aged 18 years and over. Secondary school-aged respondents were also able to take the survey with the approval of a parent or guardian. In total, 1034 respondents completed the survey. Respondents who attempted the survey but did not complete up to at least the final section consisting of optional open-ended questions were discarded and not included in the data analysis.

In regard to data analysis, basic frequencies were initially calculated through Lime Survey. Further data analysis, including cross tabulations and other tests, was conducted using Statistics Package for Social Sciences (SPSS, Version 26). In order to gain a more nuanced, qualitative understanding of the data, seven focus groups were conducted in Brisbane, Logan, Sydney, Melbourne, Canberra, Adelaide, and Perth, each involving 6-14 participants (72 participants in total). Tables, graphs, and other representations of the findings were presented in a 40-min PowerPoint presentation to the focus group participants who were then engaged by the researchers in an open conversation that covered various aspects of the survey findings. These sessions were audio recorded, transcribed, and analyzed

3 For instance, additional questions were asked of converts to Islam as well as respondents who said they believe Islam advocates a particular political system or that their freedom to practice Islam in Australia is threatened were asked to specify.

4 Ethics Reference Number: 2019/042.

5 It is worth noting that 8 in 10 Muslims in Australia have a good or very good level of English language proficiency (Hassan 2015). 
by the researchers. This process enriched the researchers' understanding of the data and was useful for gaining insights into the variations in thinking behind certain responses, contexts concerning Muslim community dynamics, and accounts of lived experiences in relation to Islam in Australia.

\section{Findings}

This section will present the survey findings in relation to the respondents' demographics and representativeness, typologies of Muslims, sources of influence about Islam, interpretation of the Qur'an, perspectives on ethical, social and theological issues, issues of concern, social connections and sense of belonging, views on various Muslim-majority countries, and perspectives concerning political Islam, including jihad, caliphate, and shariah. These questions cover the main issues and debates that have arisen in relation to Islam and Muslims over the past several years (Duderija and Rane 2019). The intention in asking these questions was to enable the voices of Muslim Australians to contribute to these debates so as to provide wider Australian society with a resource to better understand Islam and Muslims from the perspective of those who live it. A list of the survey questions is provided in Appendix A.

\subsection{Survey Respondents}

The 1034 Muslim Australian citizens and permanent residents who completed the Islam in Australia survey were representative of the Muslim Australian population in relation to a number of demographic indicators, including gender, age, country of birth, ethnic diversity, and employment status. Table 1 shows that the basic demographics of the survey respondents, in relation to gender, age, and place of birth, are closely aligned with the 2016 Australian census data concerning Muslim Australians (Australian Bureau of Statistics 2018). The survey respondents were 50.8 percent female and 49.0 percent male. In relation to place of birth, 38.7 percent were born in Australia and 61.3 percent were born overseas. It can be observed that the distributions of gender and place of birth of the sample is comparable to the 2016 Census. In terms of age, there is lower prevalence of those aged 10-19 and higher of those in their 40s in the survey sample compared to the 2016 Census. Regarding the former, the survey only allowed secondary-school-aged participants with parental approval, while the census data include ages 10 to 19 in this category.

Table 1. Demographics: Census data and survey respondents.

\begin{tabular}{ccc}
\hline Demographics & 2016 Census & 2019 Islam in Australia Survey \\
\hline Gender & & \\
Male & $53.0 \%$ & $507(49.0 \%)$ \\
Female & $47.0 \%$ & $525(50.8 \%)$ \\
Other & - & $2(0.2 \%)$ \\
Place of birth & & \\
Australia & $36.4 \%$ & $400(38.7 \%)$ \\
Overseas & $63.6 \%$ & $634(61.3 \%)$ \\
Age & & \\
19-Oct & $19.4 \%$ & $48(4.6 \%) *$ \\
20s & $18.9 \%$ & $201(19.4 \%)$ \\
$30 \mathrm{~s}$ & $19.7 \%$ & $347(33.6 \%)$ \\
$40 \mathrm{~s}$ & $11.7 \%$ & $250(24.2 \%)$ \\
$50 \mathrm{~s}$ & $7.0 \%$ & $93(9.0 \%)$ \\
60s & $3.8 \%$ & $70(6.8 \%)$ \\
70 and over & $2.1 \%$ & $24(2.3 \%)$ \\
\hline
\end{tabular}

* Note: One missing value for age. ${ }^{* *}$ Note: The survey only allowed secondary-school-aged participants with parental approval, while the census data include ages 10 to 19 in this category.

While more than half of the survey respondents were raised in Australia (56.9\%), others were raised in South Asia (22.8\%), Western Asia, including the Middle East (12.2\%), South East Asia 
(7.2\%), Europe (5.2\%), Sub-Saharan Africa (4.7\%), and Northern Africa (3.5\%), among other regions of the world. The survey also recorded the decade that respondents or their first family members arrived in Australia, which reflects the settlement pattern of Muslim Australians, overall. Of those born overseas, 56.7 percent arrived in Australia after the year 2000, 29.1 percent arrived in the 1980s-1990s, 9.3 percent arrived in the 1960s-1970s, and 1 percent arrived in the 1940s-1950s. Of the Australian-born respondents, many have resided in Australia for multiple generations as 23.7 percent had their first family member arrive in Australia before the 1940s, 7.1 percent in the 1940s-1950s, 37.7 percent in the 1960s-1970s, 18.3 percent in the 1980s-1990s, and 1.4 percent after the year 2000. The majority of the survey respondents were employed, including full-time (45.5\%), part-time (13.7\%), casual $(9.0 \%)$, students $(8.8 \%)$, or self-employed $(11.7 \%)$, while 4.3 percent were volunteers, 4.9 percent retired, and 11.9 percent were unemployed. These data reflect the higher number of unemployed among Muslim Australians relative to the wider Australia population (Hassan 2015).

In relation to education, the survey respondents were more highly educated than the Muslim Australian population overall (Hassan 2015). This is not unexpected as those who are more highly educated are more likely than those who are less educated to participate in surveys (Curtin et al. 2000; Goyder 1986; Goyder et al. 2002; Groves et al. 2000; Kandel et al. 1983; Singer et al. 1999, 2000). Over two-thirds $(68.3 \%)$ of the survey respondents had a post-secondary school qualification, including a TAFE $^{6}$ (college) certificate $(7.4 \%)$, apprenticeship (1.7\%), university undergraduate degree $(27.0 \%)$, postgraduate degree $(26.9 \%)$, or $\mathrm{PhD}(5.3 \%)$. Nineteen percent were in university at the time of the survey in an undergraduate $(10.1 \%)$, postgraduate $(6.0 \%)$, or $\mathrm{PhD}(3.1 \%)$ program. Six percent of the respondents were in high school and 5 percent had graduated high school, while 1.9 percent were at TAFE (college) and 0.2 percent had commenced an apprenticeship at the time of the survey.

Another important factor in relation to the survey respondents concerns their religiosity and religious affiliation. An overwhelming majority (86.6\%) said they "publicly/openly identify as a Muslim" and 6.2 percent said "I consider my identity as a Muslim to be a private, personal matter", while 3.6 percent said they "identify as Muslim within Muslim communities only" and 3.7 percent said "I share my identity as Muslim with friends/family only". A large majority of 77.1 percent said they prayed "daily", while 6.9 percent pray "weekly", 1.2 percent pray "monthly", 12.4 percent pray "only on occasions", and 2.5 percent said they "never pray". Perhaps unsurprising given the topic of the survey, when asked how important Islam is to their identity, 79.9 percent said "very important", 16.1 percent said "important", 2.9 percent said "not very important", and 1.2 percent said "not at all important". This is relevant as it gives the researchers confidence that the survey responses reflect those of committed Muslims, sufficiently engaged with Islam.

Given the diversity among Muslims in relation to Islam, it was also important that the survey respondents reflected the different groupings and schools of thought found among Muslims in general. Overall, when asked with what school of religious thought, group, or Islamic tradition they most identify (permitting multiple responses), a majority said "Sunni" (63.6\%), followed by a large plurality that answered "just Muslim" (34.0\%). Other responses included Hanafi (18.0\%), Ahl Sunnah wal Jamaa (12.6\%), Shafi'i (6.7\%), Sufi (6.5\%), progressive (5.2\%), Shiite (4.1\%), and Salafi (2.8\%). Over one-quarter $(27.6 \%)$ of the survey respondents were affiliated with a Muslim or Islamic association, council, committee, federation, group, movement, or society, while 72.4 percent said they were not, which also gives the researchers confidence that the survey received wide distribution and penetration into diverse communities and groupings of Muslims beyond those associated with the major representative bodies. Additionally, the survey found that 84.2 percent of respondents were born Muslim, while 15.8 percent converted to Islam. This is significant as there is no prior empirical data on the ratio of born-Muslims to converts to Islam in Australia. As it is beyond the scope of this article to examine the responses of Muslim Australian converts to Islam, this will be the focus of a forthcoming article.

6 Technical and Further Education institute. 


\subsection{Islamic Typologies}

A few academic studies have attempted to categorize Muslims according to various typologies but have not provided insight into the number of Muslims in the various categories (Duderija and Rane 2019; Saeed 2007). The Islam in Australia survey posed 10 statements, phrased according to definitions derived from the scholarly literature across a spectrum of typologies, asking "how well they describe you as a Muslim". It should be noted that respondents were provided with the statements only, not the labels, as the researchers took label avoidance into consideration in the design of these questions. Label avoidance is when people refrain from associating with particular categories or groups in order to avoid potential stigma (Ciftci et al. 2013). In Muslim communities, stigma can be associated with labels ranging from liberal, progressive, and secular to political Islamist and militant. Based on the number of respondents who answered "strongly agree" with each statement, the survey found a majority to be liberal ${ }^{7}(64.6 \%)$, followed by progressive ${ }^{8}(39.4 \%)$, secular ${ }^{9}(28.9 \%)$, traditionalist $^{10}$ (26.2\%), ethical maqasidi ${ }^{11}(25.8 \%)$, sufi ${ }^{12}(17.2 \%)$, legalist ${ }^{13}(14.4 \%)$, political Islamist ${ }^{14}(9.5 \%)$, cultural nominalist ${ }^{15}(7.9 \%)$, and militant ${ }^{16}(3.3 \%) .{ }^{17}$ It should also be noted that these typologies are not mutually exclusive but overlap in various combinations, including: Liberal and progressive; secular and liberal; liberal, ethical maqasidi and progressive; liberal, progressive, and traditionalist; ethical maqasidi and progressive; liberal and traditionalist; cultural nominalist and secular; sufi and ethical maqasidi; traditionalist and legalist; traditionalist and political Islamist; legalist and political Islamist; and political Islamist and militant.

While little comparative data are available, Goli and Rezaei (2011) found that half of the Danish Muslims included in their study adhered to some form of Islamist political thought, including those they categorized as fundamentalists $(27 \%)$, radical Islamists $(18 \%)$, and militants $(6 \%)$, which relates to the Islam in Australia survey findings in respect to traditionalists (26.2\%), legalists (14.4\%), political Islamists $(9.5 \%)$, and militants (3.3\%). However, although legalist-political and Islamist-jihadist Muslims often loom large in media images and public discourses, they represent a minority of Muslims in reality.

As shown in Table 2, some typologies differ considerably in relation to gender. Females are slightly more likely than males to identify with the liberal, progressive, ethical maqasidi, secular, and sufi typologies. Conversely, males were slightly more likely than females to identify with the traditionalist and cultural nominalist typologies but much more likely than females to identify with the legalist (males 50.1\%; females 37.1\%), political Islamist (males 28.2\%; females 14.3\%), and militant (males 9.9\%; females 5.9\%) typologies. A statistically significant difference was found in relation gender within the legalist and political Islamist typologies but not the militant typology. ${ }^{18}$

7 Statement (liberal): "I believe Islam aligns with human rights, civil liberties and democracy."

8 Statement (progressive): "I am a committed Muslim who believes in the rational, cosmopolitan nature of the Islamic tradition based on principles of social justice, gender justice and religious pluralism."

9 Statement (secular): "For me Islam is a matter of personal faith rather than a public identity."

10 Statement (traditionalist): "I am a devout Muslim who follows a traditional understanding of Islam."

11 Statement (ethical maqasidi): "I am a committed, reform-minded Muslim who emphasizes the spirit and ethical principles of Islam over literal interpretations."

12 Statement (sufi): "I am a devout Muslim who follows a more spiritual path rather than formal legal rules."

13 Statement (legalist): "I am a strict Muslim who follows Islam according to the laws of shariah."

14 Statement (political Islamist): "I am a committed Muslim who believes politics is part of Islam and advocates for an Islamic state based on shariah laws."

15 Statement (cultural nominalist): "I am a cultural Muslim for whom Islam is based on my family background rather than my practice."

16 Statement (militant): "I am a committed Muslim who believes an Islamic political order and shariah should be implemented by force if necessary."

17 Note: 15 percent of respondents did not strongly agree with any of the typologies.

18 The odds of a male identifying as a legalist was $2.080(O R)$ times greater than the odds of a female identifying as legalist, $95 \%$ CIs [1.451, 2.983], $p<0.001$. The odds of a male identifying as a political Islamist was 2.843 (OR) times greater than the odds of a female identifying as political Islamist, 95\% CIs [1.800, 4.489], $p<0.001$. The odds of a male identifying as a militant was not significantly different $(O R=1.939)$ to the odds of a female identifying as militant, $95 \%$ CIs [0.940, 3.961], $p=0.069$. 
Table 2. Typologies by gender.

\begin{tabular}{|c|c|c|c|c|c|c|}
\hline \multirow[t]{2}{*}{ Typology } & \multicolumn{2}{|c|}{$\begin{array}{c}\text { Strongly Agree/Agree } \\
(\%)\end{array}$} & \multicolumn{2}{|c|}{$\begin{array}{c}\text { Neither Agree/Disagree } \\
\text { and Unsure (\%) }\end{array}$} & \multicolumn{2}{|c|}{$\begin{array}{c}\text { Strongly } \\
\text { Disagree/Disagree (\%) }\end{array}$} \\
\hline & $\mathbf{M}$ & $\mathbf{F}$ & $\mathbf{M}$ & $\mathbf{F}$ & $\mathbf{M}$ & $\mathbf{F}$ \\
\hline \multirow[t]{2}{*}{ Liberal } & $\begin{array}{c}64.9+23.5 \\
88.4\end{array}$ & $\begin{array}{c}64.6+25.5 \\
90.1\end{array}$ & $\begin{array}{c}6.1+1.4 \\
\quad 7.5\end{array}$ & $\begin{array}{c}6.3+0.6 \\
6.9\end{array}$ & $\begin{array}{c}2.8+1.4 \\
4.1\end{array}$ & $\begin{array}{c}2.1+1.0 \\
3.0\end{array}$ \\
\hline & \multicolumn{2}{|c|}{$89.2 \%$} & \multicolumn{2}{|c|}{$7.3 \%$} & \multicolumn{2}{|c|}{$3.6 \%$} \\
\hline \multirow[t]{2}{*}{ Progressive } & $\begin{array}{c}42.0+31.0 \\
73.0\end{array}$ & $\begin{array}{c}36.8+39.8 \\
76.6\end{array}$ & $\begin{array}{c}14.0+5.5 \\
19.5\end{array}$ & $\begin{array}{c}11.8+5.7 \\
17.5\end{array}$ & $\begin{array}{c}3.2+4.3 \\
\quad 7.5\end{array}$ & $\begin{array}{c}3.0+2.3 \\
5.3\end{array}$ \\
\hline & \multicolumn{2}{|c|}{$74.8 \%$} & \multicolumn{2}{|c|}{$18.9 \%$} & \multicolumn{2}{|c|}{$6.4 \%$} \\
\hline \multirow[t]{2}{*}{ Traditionalist } & $\begin{array}{c}31.0+31.8 \\
62.7\end{array}$ & $\begin{array}{c}21.7+37.3 \\
59.0\end{array}$ & $\begin{array}{l}20.7+1.6 \\
22.3\end{array}$ & $\begin{array}{l}22.1+2.3 \\
24.4\end{array}$ & $\begin{array}{c}9.1+5.9 \\
15.0\end{array}$ & $\begin{array}{c}10.1+6.5 \\
16.6\end{array}$ \\
\hline & \multicolumn{2}{|c|}{$60.7 \%$} & \multicolumn{2}{|c|}{$23.4 \%$} & \multicolumn{2}{|c|}{$15.9 \%$} \\
\hline \multirow[t]{2}{*}{ Ethical-maqasidi } & $\begin{array}{c}27.2+30.2 \\
57.4\end{array}$ & $\begin{array}{c}24.4+35.2 \\
59.6\end{array}$ & $\begin{array}{c}21.9+3.3 \\
25.2\end{array}$ & $\begin{array}{c}21.0+4.8 \\
25.8\end{array}$ & $\begin{array}{c}10.3+7.1 \\
17.4\end{array}$ & $\begin{array}{c}10.1+4.6 \\
14.7\end{array}$ \\
\hline & \multicolumn{2}{|c|}{$58.5 \%$} & \multicolumn{2}{|c|}{$25.5 \%$} & \multicolumn{2}{|c|}{$16.0 \%$} \\
\hline \multirow[t]{2}{*}{ Secular } & $\begin{array}{c}28.0+23.3 \\
51.3\end{array}$ & $\begin{array}{l}29.7+26.5 \\
56.2\end{array}$ & $\begin{array}{c}15.4+0.1 \\
15.5\end{array}$ & $\begin{array}{l}18.7+0.4 \\
19.1\end{array}$ & $\begin{array}{c}14.2+18.1 \\
32.3\end{array}$ & $\begin{array}{c}15.2+9.5 \\
24.8\end{array}$ \\
\hline & \multicolumn{2}{|c|}{$53.8 \%$} & \multicolumn{2}{|c|}{$17.8 \%$} & \multicolumn{2}{|c|}{$28.4 \%$} \\
\hline \multirow[t]{2}{*}{ Sufi } & $\begin{array}{c}17.2+25.8 \\
43.0\end{array}$ & $\begin{array}{c}17.3+30.7 \\
48.0\end{array}$ & $\begin{array}{c}32.0+3.0 \\
35.0\end{array}$ & $\begin{array}{c}27.8+2.5 \\
30.3\end{array}$ & $\begin{array}{c}14.0+8.1 \\
22.1\end{array}$ & $\begin{array}{c}14.7+7.0 \\
21.7\end{array}$ \\
\hline & \multicolumn{2}{|c|}{$45.5 \%$} & \multicolumn{2}{|c|}{$32.6 \%$} & \multicolumn{2}{|c|}{$22.0 \%$} \\
\hline \multirow[t]{2}{*}{ Legalist } & $\begin{array}{c}18.9+31.2 \\
50.1\end{array}$ & $\begin{array}{c}10.1+27.0 \\
37.1\end{array}$ & $\begin{array}{c}22.7+2.6 \\
25.3\end{array}$ & $\begin{array}{c}30.5+2.5 \\
33.0\end{array}$ & $\begin{array}{c}14.2+10.5 \\
24.7\end{array}$ & $\begin{array}{c}18.5+11.4 \\
29.9\end{array}$ \\
\hline & \multicolumn{2}{|c|}{$43.4 \%$} & \multicolumn{2}{|c|}{$29.2 \%$} & \multicolumn{2}{|c|}{$27.4 \%$} \\
\hline \multirow[t]{2}{*}{ Political-Islamist } & $\begin{array}{c}13.8+14.4 \\
28.2\end{array}$ & $\begin{array}{c}5.3+9.0 \\
14.3\end{array}$ & $\begin{array}{c}23.9+3.9 \\
27.8\end{array}$ & $\begin{array}{c}22.9+3.4 \\
26.3\end{array}$ & $\begin{array}{c}23.3+20.7 \\
44.0\end{array}$ & $\begin{array}{c}24.4+35.0 \\
59.4\end{array}$ \\
\hline & \multicolumn{2}{|c|}{$21.1 \%$} & & & & \\
\hline Cultural & $10.1+7.7$ & $5.9+9.5$ & $11.6+1.6$ & $10.5+1.1$ & $23.1+46.0$ & $25.1+47.8$ \\
\hline Nominalist & 17.8 & 15.4 & 13.2 & 11.6 & 69.1 & 73.0 \\
\hline & & & & & & \\
\hline & $4.3+5.5$ & $2.3+3.6$ & $11.8+1.8$ & $9.3+1.9$ & $19.9+56.6$ & $20.6+62.3$ \\
\hline Militant & 9.9 & 5.9 & 13.6 & 11.2 & 76.5 & 82.9 \\
\hline & & & & & & \\
\hline
\end{tabular}

Note: Percentages are of the total male participants (507) and total female participants (525), respectively.

\subsubsection{Sources of Influence}

Respondents were asked about the influence of different sources of information for their current understanding of Islam. Based on respondents' selection of "very influential", the survey identified the most influential sources to be the Qur'an (82.5\%), followed by hadith $(66.4 \%)$, scholarly books $(41.2 \%)$, imams, sheikhs and ulema $(29.9 \%)$, family (28.4\%), academic scholars (22.2\%), mosque and madrassa classes $(21.3 \%)$, internet $(16.7 \%)$, friends $(12.3 \%)$, social media $(9.5 \%)$, school $(8.6 \%)$, and university (6.4\%). These results differ somewhat from the findings of a survey of Muslims in Canada (The Environics Institute for Survey Research 2016), which reported that the respondents' main sources of guidance were as ranked as: Local mosque/Muslim organization (22\%), family (11\%), local imam/sheikh $(10 \%)$, Qur'an/holy book (5\%), friends/community members (3\%), and self-guidance/research $(2 \%)$. 
This difference could be due to a number of factors pertaining to the respective questionnaire design, wording of the question, and/or the nature, or nurture, of the respective Muslim communities.

Overall, 77 percent of the Islam in Australia survey respondents were "completely confident" $(37.2 \%)$ or "very confident" (39.9\%) that what they have learnt about Islam is true and accurate, while an additional 19.4 percent were "somewhat confident", 2.6 percent were "not very confident", and less than 1 percent were "not at all confident" that what they have learnt about Islam is true and accurate. However, 87.8 percent were "completely" (50.9\%) or "very" (36.9\%) open to new knowledge about Islam, while 10.4 percent were "somewhat" open to new knowledge, and less than 2 percent were "not very" or "not at all" open to new knowledge about Islam. These results indicate that awareness and education programs in relation to Islam are likely to receive a positive reception among Muslim Australians, with the likelihood of a positive reception increasing if the information is derived from authentic Islamic sources and conveyed by credible, qualified scholars or trusted family members. When presented with an issue pertaining to Islam, the largest segment of respondents said they would first consult the Qur'an and Hadith (39.2\%), followed by the Qur'an only (13.8\%), contemporary traditional Islamic scholars (12.4\%), classical Islamic schools of thought $(9.5 \%)$, and contemporary progressive Islamic scholars (7.4\%). Only 0.7 percent of respondents selected "Hadith only", while 6.2 percent were "unsure", and 10.9 percent chose "other". These data provide a strong indication of the importance of Islam's primary sources, particularly the Qur'an, among Muslims for acquiring their information/knowledge about Islam and highlight the importance of interpretation of the Qur'an and Hadith.

\subsubsection{Interpreting the Qur'an}

Before looking at the Qur'an specifically, it is important to note that most respondents $(73.0 \%)$ said there is more than one valid interpretation of Islam, including "a few" $(32.4 \%)$, "many" (27.5\%), and "as many valid interpretations as there are Muslims (14.1\%), while 17.8 percent said there is "only one valid interpretation", and 8.2 percent said they are "unsure". By comparison, among US Muslims most $(64 \%)$ also say there is more than one true way to interpret Islam, while 31 percent say there is only one valid interpretation (Pew Research Center 2017). This is almost double the proportion of Muslim Australians who share this view, however, indicating that Muslim Australians are more open to multiple interpretations than their US counterparts. Globally, in 32 of 39 Muslim-majority countries surveyed by the Pew Research Center, half or more of the respondents said there is only one correct way to understand the teachings of Islam (Pew Research Center 2012), which suggests that Muslims in the West are more open to multiple interpretations than those who reside in Muslim-majority countries. This may be due to the relative homogeneity of Islam in many Muslim-majority countries versus the heterogeneity of Islam in the West resulting from the immigration of diverse groupings of Muslim from around the world. Additionally, it is important to note that Muslims in the West live within a social, political, and legal environment that offers open and safe space for discussion and debate, and are exposed to Western education, which encourages critical thinking.

The Qur'an is the primary source of Islam and also the most important source for the Islam in Australia survey respondents. Details of agreement and disagreement with various approaches to interpreting the Qur'an are shown in Table 3. Adding the number of respondents who answered "strongly agree" (SA) or "agree" (A) when asked "To what extent do you agree or disagree with the following statements regarding the reading and interpreting of the Qur'an?", 79.5 percent of respondents said "the Qur'an should be read and interpreted contextually in relation to historic and social contexts" (SA 44.5\%; A 35.0\%), 75.8 percent said "the Qur'an should be read and interpreted in relation to the principles (maqasid) of Islam" (SA 37.9\%; A 37.9\%), 68.5 percent said "some verses of the Qur'an are specific to the Prophet Muhammad's time and circumstances while others are relevant to all time and place" (SA 32.0\%; A 36.5\%), 54.6 percent "the Qur'an allows for new interpretations in response to changing conditions and realities" (SA 21.9\%; 32.7\%), 48.6 percent said "all verses of the Qur'an apply to all time, place and circumstances" (SA 30.5\%; A 18.1\%), 47.5 percent said 
"according to the interpretations of classical and contemporary scholars" (SA 10.3\%; A 37.2\%), 29.8 percent said "the Qur'an should be read and interpreted literally" (SA 15.0\%; A 14.8\%), and 16 percent said "according to the interpretations of classical scholars only (SA 4.7\%; A 11.3\%).

Table 3. Interpreting the Qur'an.

\begin{tabular}{|c|c|c|c|}
\hline Interpreting the Qur'an * & $\begin{array}{c}\text { Strongly } \\
\text { Agree/Agree }\end{array}$ & $\begin{array}{c}\text { Strongly } \\
\text { Disagree/Disagree }\end{array}$ & $\begin{array}{l}\text { Neither Agree/ } \\
\text { Disagree and } \\
\text { Unsure }\end{array}$ \\
\hline $\begin{array}{l}\text { The Qur'an should be read and } \\
\text { interpreted contextually in relation to } \\
\text { historic and social contexts }\end{array}$ & $79.5 \%$ & $5.2 \%$ & $15.2 \%$ \\
\hline $\begin{array}{l}\text { The Qur'an should be read and } \\
\text { interpreted in relation to the principles } \\
\text { (maqasid) of Islam }\end{array}$ & $75.8 \%$ & $2.6 \%$ & $21.5 \%$ \\
\hline $\begin{array}{l}\text { Some verses of the Qur'an are specific to } \\
\text { the Prophet Muhammad's time and } \\
\text { circumstances while others are relevant to } \\
\text { all times and places }\end{array}$ & $68.4 \%$ & $14.1 \%$ & $17.4 \%$ \\
\hline $\begin{array}{l}\text { The Qur'an allows for new interpretations } \\
\text { in response to changing conditions and } \\
\text { realities }\end{array}$ & $54.6 \%$ & $20.1 \%$ & $25.3 \%$ \\
\hline $\begin{array}{l}\text { All verses of the Qur'an apply to all time, } \\
\text { place and circumstances }\end{array}$ & $48.5 \%$ & $32.7 \%$ & $18.6 \%$ \\
\hline $\begin{array}{l}\text { The Qur'an should be understood } \\
\text { according to the interpretations of } \\
\text { classical and contemporary scholars }\end{array}$ & $47.4 \%$ & $18.5 \%$ & $33.9 \%$ \\
\hline $\begin{array}{l}\text { The Qur'an should be read and } \\
\text { interpreted literally }\end{array}$ & $29.8 \%$ & $43.9 \%$ & $26.3 \%$ \\
\hline $\begin{array}{l}\text { The Qur'an should be understood } \\
\text { according to the interpretations of } \\
\text { classical scholars only }\end{array}$ & $16.0 \%$ & $51.8 \%$ & $32.1 \%$ \\
\hline
\end{tabular}

* Question: "To what extent do you agree or disagree with the following statements regarding the reading and interpreting of the Qur'an?".

These findings offer more detailed insights as to how Muslims in the West think the Qur'an should be interpreted and cohere with other studies. For instance, US Muslims also say traditional understandings of Islam need to be reinterpreted in light of modern contexts (52\%) rather than saying that traditional understandings are sufficient (38\%) (Pew Research Center 2017).

\subsection{Ethical, Social and Theological Issues}

The survey asked a number of questions pertaining to social and interpersonal relations, human rights, and theology. Adding the number of respondents who answered "strongly agree" or "agree" to the statements provided, the survey found that respondents overwhelmingly expressed ethical, liberal, progressive views consistent with the above-mentioned typologies. As shown in Table 4, in relation to spousal relations, 95.2 percent said "marriage should be based on mutual respect rather than the subservience of one spouse to the other". Concerning human equality, 92.6 percent said "people of all religion and no religion should be treated equally", 84.1 percent said "women should be given the same rights and opportunities as men", and 93.9 percent said "indigenous people should be 
recognized in Australia's constitution". ${ }^{19}$ These findings refute claims that Muslims are opposed to equality between spouses and people in general as a standard within Islam.

Table 4. Ethical, social, and theological issues by gender.

\begin{tabular}{|c|c|c|c|c|c|c|}
\hline \multirow[t]{2}{*}{ Issue } & \multicolumn{2}{|c|}{$\begin{array}{c}\text { Strongly } \\
\text { Agree/Agree }\end{array}$} & \multicolumn{2}{|c|}{$\begin{array}{c}\text { Strongly } \\
\text { Disagree/Disagree }\end{array}$} & \multicolumn{2}{|c|}{$\begin{array}{l}\text { Neither Agree/ } \\
\text { Disagree and } \\
\text { Unsure }\end{array}$} \\
\hline & $\mathbf{M}$ & F & $\mathbf{M}$ & F & $\mathbf{M}$ & $\mathbf{F}$ \\
\hline \multirow{2}{*}{$\begin{array}{l}\text { "Women should be given the same right } \\
\text { and opportunities as men" }\end{array}$} & 80.6 & 87.6 & 6.5 & 5.1 & 12.8 & 7.2 \\
\hline & \multicolumn{2}{|c|}{$84.1 \%$} & \multicolumn{2}{|c|}{$5.8 \%$} & \multicolumn{2}{|c|}{$9.9 \%$} \\
\hline \multirow{2}{*}{$\begin{array}{l}\text { "Marriage should be based on mutual } \\
\text { respect rather than the subservience of } \\
\text { one spouse to the other" }\end{array}$} & 94.0 & 96.5 & 2.1 & 1.3 & 3.7 & 2.0 \\
\hline & \multicolumn{2}{|c|}{$95.2 \%$} & \multicolumn{2}{|c|}{$1.7 \%$} & \multicolumn{2}{|c|}{$2.9 \%$} \\
\hline \multirow{2}{*}{$\begin{array}{l}\text { "People of all religions and no religion } \\
\text { should be treated equally" }\end{array}$} & 89.9 & 95.4 & 4.7 & 1.3 & 5.3 & 3.2 \\
\hline & \multicolumn{2}{|c|}{$92.6 \%$} & \multicolumn{2}{|c|}{$3.0 \%$} & \multicolumn{2}{|c|}{$4.2 \%$} \\
\hline \multirow{2}{*}{$\begin{array}{l}\text { "Abiding by Australian laws does not } \\
\text { equate to disobedience to Allah" }\end{array}$} & 85.8 & 88.7 & 4.3 & 2.4 & 9.8 & 8.7 \\
\hline & \multicolumn{2}{|c|}{$87.2 \%$} & \multicolumn{2}{|c|}{$3.3 \%$} & \multicolumn{2}{|c|}{$9.3 \%$} \\
\hline \multirow{2}{*}{$\begin{array}{l}\text { "Taking the citizenship pledge (in } \\
\text { the name of God) equates to } \\
\text { a religiously-binding oath" }\end{array}$} & 62.9 & 56.9 & 10.0 & 9.9 & 27.0 & 33.1 \\
\hline & \multicolumn{2}{|c|}{$59.8 \%$} & \multicolumn{2}{|c|}{$9.9 \%$} & \multicolumn{2}{|c|}{$30.1 \%$} \\
\hline \multirow{2}{*}{$\begin{array}{l}\text { "Indigenous people should be recognized } \\
\text { in Australia's constitution" }\end{array}$} & 93.4 & 94.4 & 1.7 & 0.3 & 4.7 & 5.1 \\
\hline & \multicolumn{2}{|c|}{$93.9 \%$} & \multicolumn{2}{|c|}{$1.0 \%$} & \multicolumn{2}{|c|}{$4.9 \%$} \\
\hline \multirow{2}{*}{$\begin{array}{l}\text { "Environmental sustainability should be } \\
\text { given higher priority in Islamic discourse" }\end{array}$} & 84.4 & 81.9 & 1.9 & 1.9 & 13.6 & 16.2 \\
\hline & \multicolumn{2}{|c|}{$83.0 \%$} & \multicolumn{2}{|c|}{$1.9 \%$} & \multicolumn{2}{|c|}{$14.9 \%$} \\
\hline \multirow{2}{*}{$\begin{array}{l}\text { "Halal certifiers should assess the ethical } \\
\text { treatment of animals as part of the halal } \\
\text { certification process" }\end{array}$} & 90.7 & 93.1 & 2.9 & 0.9 & 6.3 & 5.9 \\
\hline & \multicolumn{2}{|c|}{$91.8 \%$} & \multicolumn{2}{|c|}{$1.9 \%$} & & \\
\hline "There needs to be more emphasis on & 76.9 & 78.2 & 2.5 & 3.2 & 20.5 & 18.4 \\
\hline when teaching Islam" & & & & & & \\
\hline "Someone who dies attacking innocent & 93.6 & 93.1 & 2.5 & 1.7 & 3.7 & 5.1 \\
\hline civilians is not a martyr (shaheed)" & & & & & & \\
\hline
\end{tabular}

Note: Percentages are of the total male participants (507) and total female participants (525), respectively.

The survey also asked six additional questions concerning matters of theology and ethics to which the overwhelming majority of respondents also expressed ethical, liberal, progressive views. Adding the number of respondents who selected "strongly agree" or "agree" showed that 93.3 percent said "someone who dies attacking innocent civilians is not a martyr", 91.8 percent said "halal certifiers should assess the ethical treatment of animals as part of the halal certification process", 87.2 percent said "abiding by Australian law does not equate to disobedience to Allah", and 83.0 percent said "environmental sustainability should be given higher priority in Islamic discourse". A large majority strongly agreed or agreed that "there needs to be more emphasis on Islamic ethics rather than jurisprudence when teaching Islam" (77.5\%), while a majority also said "taking the citizenship pledge (in the name of God) equates to a religiously-binding oath" (59.8\%). The response to the latter

19 In comparison, $70 \%$ of the general Australian population support or strongly support Indigenous recognition in the Australian Constitution (Essential Research 2019). 
question suggests that the Islamic requirement to uphold agreements, contracts, and oaths, addressed in detail by March (2011), has resonance among Muslim Australians. However, that 30.1 percent of respondents neither agreed or disagreed or were unsure about this question suggests that it requires further discussion within Muslim communities. Overall, these findings refute claims central to anti-Islam/anti-Muslim bigotry that Islam promotes cruelty to animals, violence (including domestic violence), and criminality (Wood 2013; Gleeson and Baird 2017; Rane 2019). Rather, these results show that Muslim Australians align their faith with principles of equality, social justice, human rights, animal welfare, and environmental sustainability.

\subsection{Issues of Concern}

The survey asked respondents about their level of concern in regard to 15 global, national, and social issues. By adding the number of respondents who said they are "very concerned" or "concerned", the survey found the highest levels of concern for media reporting on Islam and Muslims (95.6\%) and discrimination against Muslims (95.0\%), followed by anti-Islam sentiments (94.0\%), terrorism by right-wing extremists (93.1\%), domestic violence $(92.7 \%)$, mental health $(92.6 \%)$, affordable housing $(92.1 \%)$, treatment of asylum seekers (89.1\%), climate change (88.5\%), terrorism by Muslim extremists (88.1\%), affordable higher education (86.8\%), economic inequality (86.7\%), Australian military intervention in Muslim-majority countries (85.6\%), unemployment $(84.7 \%)$, and reconciliation with indigenous Australians (81.7\%). While these results show that issues specific to the treatment of Muslims are of major concern, other issues that concern society, the economy, and the planet more generally are also among the major concerns of Muslim Australians.

When asked to what extent they agreed that their freedom to practice Islam is threatened in Australia, 34.3 percent of the survey respondents disagreed that it is and 12.4 percent strongly disagreed. However, 21.3 percent agreed and 6.3 percent strongly agreed their freedom to practice Islam is threatened in Australia and were asked to specify as to why they thought so. Short-answer responses from the survey participants provide further insight into these concerns. Echoing the sentiments of others, in the words of one survey participant: "The media is quite unethical and affecting [sic] our image negatively and slowly making it very hard to survive at work, street or anywhere we go, by stigmatizing us". In addition to media bias, political rhetoric was also cited as a cause of diminished freedom of religion. In the words of another survey participant: "politicians and commentators claiming through the media that Islam is not compatible with the Australian way of life or discuss other misconceptions on Islam in order to relate to political issues". These sentiments were echoed by another participant: "politicians are using Islam as a means to gain votes by scaring non-Muslims". Overall, the responses of the 214 respondents that strongly agreed or agreed their freedom to practice Islam is threatened in Australia were examined. They referred to pejorative political discourses and rhetoric $(N$ $=57)$, media reporting and representation $(N=50)$, right-wing extremism $(N=30)$, discrimination against attire including hijab and niqab $(N=30)$, Islamophobia $(N=25)$, public sentiments and verbal insults $(N=20)$, opposition to the building of mosques or Islamic schools $(N=16)$, workplace and labor-market discrimination $(N=14)$, misunderstanding and misinformation about Islam $(N=13)$, hate crimes including vandalism and attacks on mosques $(N=11)$, countering violent extremism programs and anti-terror laws $(\mathrm{N}=10)$, social stigma, judgement and negativity $(N=9), \operatorname{racism}(N$ $=8)$, anti-halal campaigns $(N=6)$, and anti-Muslim agenda $(N=5)$. These findings indicate that while a large majority of Muslim Australians are concerned about anti-Islam/anti-Muslim sentiments, rhetoric, discourses, and discrimination, a minority $(27.6 \%)$ perceive this as threatening to the practice of their faith.

\subsection{Social Connections and Sense of Belonging}

Respondents were asked a series of questions concerning social connections, engaging with non-Muslims, and levels of trust in social institutions. As shown in Table 5, when asked how "involved, connected and a sense of belonging" they feel in relation to various social groups, networks, and 
institutions, the number of respondents who said their sense of connection/belonging was "very strong" or "strong" was found to be highest in relation to family and friends $(80.4 \%)$, followed by the Muslim community (46.3\%), school, university, or workplace $(45.5 \%)$, local mosque $(38.3 \%)$, neighborhood (28.6\%), wider Australian society (25.3\%), sports, recreation, or other clubs (22.0\%). and the Australian political system (14.6\%). These findings are similar to some reported among the general Australian population. The 2018 Australian Loneliness Report found that Australians were most connected to family, while the level of connection to their neighbors was weakest, with approximately one-third (34\%) having "no neighbors they see or hear from on a monthly basis" and close to half (47\%) having no neighbors they could call for help. Like the Islam in Australia survey, connections to friends were also strong, with the survey finding that "most Australians (92\%) have at least one friend that they see at least once a month, and they can talk to about private matters (88\%) or get help from (88\%)" (Australian Psychological Society 2018).

Table 5. Social connections and sense of belonging *.

\begin{tabular}{ccccccc}
\hline $\begin{array}{c}\text { Social Connection and } \\
\text { Belonging }\end{array}$ & $\begin{array}{c}\text { Very } \\
\text { Strong }\end{array}$ & Strong & Moderate & Weak & $\begin{array}{c}\text { Very } \\
\text { Weak }\end{array}$ & N/A \\
\hline Family and Friends & $51.4 \%$ & $29.0 \%$ & $14.6 \%$ & $2.4 \%$ & $1.3 \%$ & $1.1 \%$ \\
Neighborhood & $10.5 \%$ & $18.1 \%$ & $39.7 \%$ & $19.5 \%$ & $10.1 \%$ & $1.8 \%$ \\
Local Mosque & $16.8 \%$ & $21.5 \%$ & $13.8 \%$ & $15.0 \%$ & $10.9 \%$ & $3.7 \%$ \\
Muslim Community & $16.8 \%$ & $29.5 \%$ & $34.7 \%$ & $12.3 \%$ & $5.4 \%$ & $1.0 \%$ \\
School/University/Workplace & $16.0 \%$ & $29.5 \%$ & $30.0 \%$ & $9.4 \%$ & $4.2 \%$ & $10.6 \%$ \\
Sporting/Social Clubs & $6.5 \%$ & $15.5 \%$ & $26.6 \%$ & $18.6 \%$ & $10.3 \%$ & $22.2 \%$ \\
Wider Australian Society & $6.8 \%$ & $18.5 \%$ & $43.4 \%$ & $17.5 \%$ & $9.7 \%$ & $3.8 \%$ \\
Australian Political System & $4.6 \%$ & $10.0 \%$ & $31.6 \%$ & $25.5 \%$ & $20.8 \%$ & $7.2 \%$ \\
\hline
\end{tabular}

* Question: In relation to the following social groups/contexts, how strongly do you feel involved, connected and a sense of belonging?

In part, gender may be a contributing factor to disconnection in some contexts. For example, the focus group discussions highlighted that women are often excluded or feel excluded from mosques. In the words of one participant in Brisbane (P4): "the reality is most Muslim women don't have a connection with the mosque. They don't feel welcome at all ... you're made to feel that you're not welcome." This view was supported by several other participants, including one in Melbourne (P3) who noted that she was not surprised by lower levels of connection to mosques among women: "women in general have less access to the mosques or involvement in the mosques." These sentiments were echoed in other cities as well: "women don't feel as welcome in the mosque as men do" (Canberra, P8). Others also mentioned insufficient space in mosques to accommodate women: "there are mosques that if a woman wants to go there on a Friday, especially the smaller mosques, there is no room for women" (Sydney, P8).

\section{Engaging with Non-Muslims}

When asked what they think about "engaging with non-Muslims as family, friends, colleagues and in general social interaction", 92.2 percent of the survey respondents said this is "normal and good", while 5.7 percent said "engaging with non-Muslims should be primarily done for $d a^{\prime} w a h$ (proselytizing)" and very few respondents answered that engaging with non-Muslims "is discouraged in Islam" $(N=9,0.9 \%)$, "forbidden" $(N=2,0.2 \%)$, or were "unsure" $(N=11,1.1 \%)$. These findings refute suggestions that ideas propagated by Wahhabis and some Salafis, namely alwala wal bara (loyalty to Muslims and disavowal of non-Muslims), and interpretations that claim Islam disfavors, proscribes, or forbids friendship between Muslims and non-Muslims (Shavit 2014), resonate with Muslim Australians. Rather, the survey results show that Muslim Australians overwhelmingly reject notions that engaging with non-Muslims somehow contradicts the teachings of Islam. 


\subsection{Trust in Social Institutions and Policies}

The survey asked respondents how trustworthy they consider a number of social institutions and policies in relation to whether they perform their functions effectively, fairly, and honestly. By adding the number of respondents who said they considered the institution or policy to be "very trustworthy" or "trustworthy", we found the highest level of trust in the judiciary $(64.8 \%)$ and public schools $(64.6 \%)$, followed by law-enforcement agencies (58.7\%), defense forces (36.6\%), security/intelligence agencies $(32.1 \%)$, and parliament $(28.7 \%)$. By adding the number of respondents who answered that they considered the institution to be "not very" or "not at all" trustworthy, we found parliament (61.4\%) tops the list, followed by security/intelligence agencies (51.4\%), the defense forces (45.7\%), law-enforcement agencies $(31.9 \%)$, the judiciary $(26.7 \%)$, and public schools $(21 \%)$. The relatively high level of trust in the law-enforcement agencies may be due to the significant engagement of police services with Muslim communities over the past two decades. At the other end of the spectrum, the more secretive nature of security/intelligence agencies and recent concerns of war crimes in Afghanistan committed by Australian defense force personnel (Greene 2019) may have contributed to lower levels of trust in these institutions.

In regard to Muslim community organizations, respondents expressed the most trust for Islamic schools and colleges (52.3\%), the national board of imams (48.9\%), state board of imams $(49.4 \%)$, and state Islamic councils (46.1\%), followed by the Australian Federation of Islamic Councils ( $42.3 \%)$. It is noteworthy that only a slight majority expressed trust in Islamic schools, while the other organizations fell short of a majority. The organizations respondents considered to be "not very" or "not at all" trustworthy were the Australian Federation of Islamic Councils (33.0\%), followed by Islamic schools and colleges $(25.1 \%)$, state Islamic councils $(22.2 \%)$, state board of imams $(21.3 \%)$, and national board of imams (20.3\%). The focus groups relayed similar sentiments with participants elaborating that they felt a "lack of transparency" (Perth, P13) was hindering trust. Similarly, another focus group participant from Perth (P1) went on to note their feelings towards these organizations could be surmised by a "lack of honesty, lack of integrity, lack of leadership, lack of adding value to community, ego. It's all about them". Overall, these findings show that Muslim Australians are not uncritical of Muslim organizations. That these organizations (with the marginal exception of Islamic schools) have not gained the trust of a majority of Muslim Australians may be due in part to an unfamiliarity with them among a significant plurality of respondents. However, another a contributing factor seems to be certain failings in the operations or conduct of these organizations, which are known within Muslim communities and have occasionally been reported in mainstream media (Morton 2017).

Concerning trust in policies, the most trust was expressed in Australia's multicultural policy (53.8\%), which was the only policy trusted by the majority of respondents. Trust in other policies was far less, including border protection policy (32.4\%), counter-terrorism policy $(27.0 \%)$, and countering violent extremism policy (26.2\%). Among the policies considered "not very" or "not at all" trustworthy were counter-terrorism policy $(50.4 \%)$, followed by border protection policy $(47.7 \%)$, countering violent extremism policy (43.2\%), and multicultural policy (27.6\%). These findings are perhaps unsurprising given the positive regard Muslims are generally recorded to have in relation to multiculturalism, their concern with border protection policies, and stigma Muslim Australians have experienced in relation to counterterrorism and countering violent extremism policies (Dunn et al. 2016).

\subsection{Views on Muslim-Majority Countries}

Respondents were asked about the impact of a number of Muslim-majority countries on the understanding and practice of Islam on Muslims in general over the past few decades. The countries that respondents were asked to rate included Egypt, Indonesia, Iran, Malaysia, Morocco, Pakistan, Qatar, Saudi Arabia, and Turkey. These are Muslim-majority countries that are active in education about Islam, with prominent Islamic educational institutions, and influential in respect to the global image of Islam. By adding the number of respondents who said the country has had a "very positive" or "positive" impact, the survey found the most positively regarded countries to be Malaysia (52.3\%) 
and Turkey (51.6\%), followed by Indonesia (36.3\%), Qatar (28.0\%), Morocco (26.0\%), Pakistan (17.7\%), Egypt (15.3\%), Saudi Arabia (13.0\%), and Iran (9.8\%). However, by adding the number of respondents who said the country has had a "negative" or "very negative" impact, the survey found the most negatively regarded country to be Saudi Arabia (63.0\%), followed by Iran (52.2\%), Pakistan $(39.7 \%)$, Egypt (37.6\%), Qatar (18.4\%), Indonesia (15.0\%), Turkey (12.2\%), Malaysia (7.0\%), and Morocco (6.3\%).

This suggests a preference for countries that are more open, tolerant, and democratic and an aversion for those that are more closed, intolerant, and authoritarian. However, the notably strong negativity towards Saudi Arabia may also be due to its role in promoting Islamist-jihadism and Wahhabism associated with groups such as Al Qaeda and ISIS, war crimes in Yemen, and brutal murder of journalist Jamal Khashoggi among other human rights violations that have received widespread attention in recent years. Akyol (2019) contends that Muslims globally are turning away from political Islam because they are "disillusioned with the ugly things done in the name of their religion", including the "civil wars, authoritarian rule, hate-filled teaching" of Islamic movements, Islamist regimes, and militant groups like ISIS. A follow-up, open-ended question asked the survey respondents "among the various countries in the world, which do you think best upholds the values of Islam as you understand them". This was an optional question, of which 650 respondents answered. The responses given resemble the above-cited with Turkey receiving 132 and Malaysia 123 first mentions. Among the other prominently mentioned Muslim-majority countries were Indonesia $(N=33)$, Saudi Arabia $(N$ =32), $\operatorname{Iran}(N=21)$, Pakistan $(N=18)$, Qatar $(N=12)$, and Brunei $(N=12)$. However, it is noteworthy that many Western countries were mentioned including New Zealand $(N=17)$, Australia $(N=13)$, and Canada $(N=10)$. Another 76 respondents said that no country in the world upholds the values of Islam today.

\subsection{Political Islam}

\subsubsection{Jihad}

Over the past few decades, issues involving armed conflict, politics, and law, including jihad, caliphate, and shariah, have dominated Western perceptions of Islam. The survey asked respondents questions about each of these issues in order to identify how Muslim Australians understand these contentious terms, how they perceive them in relation to Islamic teachings, and potential implications of these ideas/concepts for relations with non-Muslims and wider society. In relation to jihad, respondents were asked about their understanding of the term according to how it is used in the Qur'an and in the example of the Prophet Muhammad. In response, 68.3 percent said jihad means "to strive/struggle through spiritual, charitable or good deeds, including armed struggle in self-defense only", while 18.8 percent said it also includes "offensive armed struggle", 8.0 percent selected "don't know/unsure", and 4.9 percent chose "other". Many of the survey responses given by those who selected "other" as well as the focus group participants revealed that jihad is understood as an inner, spiritual struggle without the component of armed struggle. Many focus group participants made statements similar to this one in Adelaide (P1): "jihad firstly is an internal struggle ... actual warfare is a small part of it." Another focus group participant suggested that the 18.8 percent who referred to "offensive jihad" did so in relation to "fighting back" against "aggressive" Western military intervention in Muslim countries but that "deep inside I think we all believe jihad is an internal struggle and self-defence only" (Canberra, P2). Other responses also viewed the term "offensive armed struggle" to include defending Muslims overseas who are under attack to repel an aggressor or oppressor, as was suggested at a number of the focus group sessions around the country. In the words of a few respondents, this understanding of jihad includes: "to defend the human rights of others", "to free others from invasion and oppression", and "struggle against the oppression of innocent people". This would imply a defensive rather than an offensive understanding of jihad. Taking this into consideration, it would seem that less than 18.8 percent of Muslim Australians may actually understand jihad to be offensive and that the proportion 
who understand it to be defensive only may be higher than the quantitative data suggest. Responses to subsequent questions concerning jihad add weight to this view.

When asked, "In relation to armed conflict, what is your understanding of how Islam regards civilians/non-combatants?", 89.5 percent answered "Islam never permits armed conflict against civilians/non-combatants", while only 4 percent said "Islam sometimes permits armed conflict against civilians/non-combatants", less than 1 percent $(0.9 \%)$ said "Islam generally permits armed conflict against civilians/non-combatants", and 5.7 percent said "don't know/unsure". These responses increase the researchers' confidence that jihad is overwhelmingly understood as defensive rather offensive by Muslim Australians, which is also the view of the majority of classical and contemporary Islamic scholars (Al-Dawoody 2011; Rane 2009). Additionally, it is worth recalling the above-cited finding that an overwhelming majority of 93.3 percent agreed or strongly agreed that "someone who dies attacking innocent civilians is not a martyr".

\subsubsection{Caliphate}

Respondents were asked a number of questions about the relationship between Islam and politics and the institution of the caliphate. When asked, "Do you believe Islam advocates a particular political system, 24.5 percent selected "yes", while 49.1 percent selected "no", and 26 percent selected "don't know/unsure". Those who said "yes" $(N=253)$ were asked about contemporary Muslim-majority states that self-identify as "Islamic", including Saudi Arabia, Iran, Pakistan, and the so-called Islamic State of Iraq and Syria (ISIS). Very few respondents regarded these as "Islamic": Saudi Arabia ( $N=$ $51,17 \%)$, Iran $(N=36,12 \%)$, Pakistan $(N=28,9 \%)$, and ISIS $(N=16,5 \%)$. Most respondents $(60 \%)$ selected "other" and then said "none" when asked to name a state or political system they consider to be legitimately Islamic. These findings suggest that a minority of Muslim Australians believe Islam advocates a particular political system, while most do not think so. Moreover, the size of this minority seems to shrink when asked to identify an Islamic state or Islamic political system.

When asked whether the form of government referred to as a khilafah/caliphate is a religious obligation, 9.3 percent strongly agreed, 13.9 percent agreed, 20.1 percent neither agreed nor disagreed, 20.1 percent disagreed, 18.2 percent strongly disagreed, and 17.9 percent were unsure. While little comparative data are available, a Pew Research Center survey found that clear majorities of participants in Pakistan (74\%), Morocco (71\%), and Egypt (67\%), as well as slightly less than half $(49 \%)$ the respondents in Indonesia, supported the notion of unifying "all Islamic countries into a single Islamic state or caliphate" (Kull 2007). The Qur'an and statements attributed to the Prophet Muhammad do not provide details on implementing a particular political system let alone command one called a khilafah or caliphate. Rather, this system of governance was developed by Muslims after the death of the Prophet Muhammad and came to be regarded as a religious obligation by some Islamic scholars in the following centuries (Razek 2013). However, in modern times, following the abolition of the Ottoman empire/caliphate by the Republic of Turkey, there have been sporadic movements to reestablish a caliphate, the most recent of which have included groups such as Hizbut Tahrir, $\mathrm{Al}$ Qaeda, and ISIS. Given that over one-fifth of the survey respondents do think the caliphate is a religious obligation, while another one-fifth neither agreed nor disagreed, and about 18 percent are unsure, this is another issue about which more awareness and education is needed, especially considering the main proponents of this idea in recent years are associated with violent extremism and use it as part of their recruitment propaganda (Mahood and Rane 2017).

\subsubsection{Shariah}

When asked about their understanding of the term shariah, a slight majority (51.1\%) of the Islam in Australia survey respondents answered that it refers to "Islamic jurists' opinions and interpretations based on the Qur'an and other sources", while 36.4 percent said it is a "divine/revealed law/legal code", 9 percent selected "don't know/unsure", and 3.6 percent selected "other". Among the latter were a few responses that identified the Qur'anic definition of shariah as "path" or a "way" (Quran 45:18; 
42:13). It is noteworthy that the idea of shariah as "law" did not exist during the time of the Prophet Muhammad and that the terms figh and shariah were not evidenced in the canonical hadith compendia in reference to jurisprudence or a legal code (Farooq and El-Ghattis 2018; Kamali 2006). The Islamic jurists of the classical era from around the 8th century developed the concept of shariah as an ideal expression of Allah's will, which encompassed the beliefs, ethics, morals, values, and laws of Islam. In modern times, particularly since the latter half of the 20th century, the idea of shariah has evolved further to become closely associated with the idea of a legal code (Hallaq 2009).

In a global context, Muslims today are more likely to say shariah is the revealed word of God rather than a legal code developed by men. A study by the Pew Research Center (2013), found in 17 of the 23 countries surveyed "at least half of Muslims say shariah is the revealed word of God" and "in no country are Muslims significantly more likely to say shariah was developed by men than to say it is the revealed word of God." Given that Islamist and jihadist groups have appropriated the term shariah as central to their cause and the trepidation it evokes among non-Muslims, especially those on the far-right, there is a need for a critical-analytical, evidence-based understanding of this term, including its use in the Qur'an and by the Prophet Muhammad, and the evolution of its meaning from the classical era of Islamic civilization to the modern times through to its appropriation by Islamist and jihadist groups.

Although a large minority of the survey respondents do not seem to recognize the human hand in the historic development of the legal system referred to as shariah and instead consider shariah to be a divine law, this should not be interpreted as detrimental to social relations. The survey asked a number of questions concerning respondents' views on practicing or implementing shariah as well as their agreement and disagreement with a number of questions concerning shariah and society. By adding the number of respondents who answered "strongly agree" or "agree" the survey found that 73.9 percent are "content with the extent to which Muslims are currently able to practice Islam in Australia" and 71.6 percent said "Australia's legal system upholds the principles of justice and I am generally satisfied with it". A slight majority (51.7\%) "would like classical shariah laws relating to family matters such as marriage, divorce, and inheritance recognized in Australian law", while 20.4 percent "would like to live in a country where polygamy is legal", 17.9 percent "would like to live in a country where classical shariah punishments are implemented", and only 9.6 percent think that "counties today that implement classical shariah laws are more just and fair than Australia". It is noteworthy that questions related to shariah also differed by gender with males more likely than female respondents to support the implementation of shariah. As shown in Table 6, males are more than twice as likely as females to say they want to live in a country in which classical shariah punishments are implemented. ${ }^{20}$ The gender disparity can also be seen in relation to family matters, with males 18 percent more likely than females to agree or strongly agree with having the classical shariah laws pertaining to marriage, divorce, and inheritance recognized in Australian law. ${ }^{21}$ Males were also found to be four times more likely than females to want to live in a country where polygamy is legal. ${ }^{22}$

20 Expressed differently, the odds of a male wanting to live in a country with shariah punishment was 2.750 (OR) times greater than the odds of a female wanting this, 95\% CIs [1.955, 3.867], $p<0.001$.

21 Expressed differently, the odds of a male wanting family-related shariah laws 2.190 (OR) times greater than the odds of a female wanting this, $95 \%$ CIs $[1.696,2.823], p<0.001$.

22 Expressed differently, the odds of a male wanting to live in a country with legalised polygamy was $5.163(\mathrm{OR})$ times greater than the odds of a female wanting this, 95\% CIs [3.615, 7.374], $p<0.001$. 
Table 6. Shariah and society by gender.

\begin{tabular}{|c|c|c|c|c|c|c|}
\hline \multirow[t]{2}{*}{ Statement } & \multicolumn{2}{|c|}{$\begin{array}{c}\text { Strongly } \\
\text { Agree/Agree }\end{array}$} & \multicolumn{2}{|c|}{$\begin{array}{c}\text { Strongly } \\
\text { Disagree/Disagree }\end{array}$} & \multicolumn{2}{|c|}{$\begin{array}{l}\text { Neither Agree nor } \\
\text { Disagree/Unsure }\end{array}$} \\
\hline & Male & Female & Male & Female & Male & Female \\
\hline \multirow{2}{*}{$\begin{array}{l}\text { I am content with the extent to which } \\
\text { Muslims are currently able to practice } \\
\text { Islam in Australia }\end{array}$} & $74.8 \%$ & $73.1 \%$ & $12.0 \%$ & $13.5 \%$ & $13.2 \%$ & $13.3 \%$ \\
\hline & \multicolumn{2}{|c|}{$73.9 \%$} & \multicolumn{2}{|c|}{$12.8 \%$} & \multicolumn{2}{|c|}{$13.4 \%$} \\
\hline \multirow{2}{*}{$\begin{array}{l}\text { Australia's legal system upholds } \\
\text { principles of justice and I am generally } \\
\text { satisfied with it }\end{array}$} & $75.0 \%$ & $68.6 \%$ & $12.2 \%$ & $13.9 \%$ & $12.8 \%$ & $17.5 \%$ \\
\hline & \multicolumn{2}{|c|}{$71.6 \%$} & \multicolumn{2}{|c|}{$13.2 \%$} & \multicolumn{2}{|c|}{$15.3 \%$} \\
\hline \multirow{2}{*}{$\begin{array}{l}\text { I would like classical shariah laws } \\
\text { relating to family matters, such as } \\
\text { marriage, divorce and inheritance, } \\
\text { recognized in Australian law }\end{array}$} & $60.9 \%$ & $42.9 \%$ & $14.2 \%$ & $27.0 \%$ & $24.9 \%$ & $30.1 \%$ \\
\hline & \multicolumn{2}{|c|}{$51.7 \%$} & \multicolumn{2}{|c|}{$20.7 \%$} & \multicolumn{2}{|c|}{$27.7 \%$} \\
\hline \multirow{2}{*}{$\begin{array}{l}\text { I would like to live in a country where } \\
\text { polygamy (polygyny: a man marrying } \\
\text { multiple women) is legal }\end{array}$} & $32.5 \%$ & $8.8 \%$ & $29.8 \%$ & $63.4 \%$ & $37.7 \%$ & $27.8 \%$ \\
\hline & \multicolumn{2}{|c|}{$20.4 \%$} & \multicolumn{2}{|c|}{$46.9 \%$} & \multicolumn{2}{|c|}{$32.7 \%$} \\
\hline \multirow{2}{*}{$\begin{array}{l}\text { I would like to live in a country where } \\
\text { classical shariah punishments are } \\
\text { implemented }\end{array}$} & $25.0 \%$ & $11.0 \%$ & $41.6 \%$ & $60.8 \%$ & $33.1 \%$ & $28.2 \%$ \\
\hline & \multicolumn{2}{|c|}{$17.9 \%$} & \multicolumn{2}{|c|}{$51.4 \%$} & \multicolumn{2}{|c|}{$30.8 \%$} \\
\hline \multirow{2}{*}{$\begin{array}{l}\text { Countries today that implement } \\
\text { classical shariah laws are more just } \\
\text { and fair than Australia }\end{array}$} & $11.6 \%$ & $7.6 \%$ & $59.8 \%$ & $60.4 \%$ & $28.6 \%$ & $32.0 \%$ \\
\hline & \multicolumn{2}{|c|}{$9.6 \%$} & \multicolumn{2}{|c|}{$60.1 \%$} & \multicolumn{2}{|c|}{$30.4 \%$} \\
\hline
\end{tabular}

Note: Percentages are of the total male participants (507) and total female participants (525) respectively.

\subsubsection{Democracy}

Since the latter half of the 20th century some Islamist, Salafist and jihadist groups have advocated the idea that Islam and democracy are incompatible (Anjum 2016), which has contributed to confusion among a minority of Muslims regarding the religious permissibility of political participation in democratic countries. This view has most prominently been promoted by extremist groups such as $\mathrm{Al}$ Qaeda and ISIS but rejected by other Islamist groups including the Muslim Brotherhood and related parties, which have participated in democratic elections in their respective countries when permitted (Roy 1994; Bayat 2013). The Islam in Australia survey asked respondents "Is Islam compatible with the principles of democracy?", to which over 80 percent agreed that Islam is "completely" $(42.5 \%)$ or "mostly" (38.5\%) compatible with democracy, while only 5.8 percent said it is "not very", 4.1 percent said it's "not at all" compatible and 9.2 percent were "unsure" about Islam's compatibility with democracy. Comparatively, a poll conducted by the Pew Research Center (2017) found that 65 percent of American Muslims felt that there was no conflict between Islam and democracy, while 30 percent believed that there was "an inherent conflict between Islam and democracy".

The survey also inquired about respondents' views on specific principles of democracy. By adding the number of respondents who answered "strongly agree" or "agree", the survey found strong support for the principles of democracy, including: "freedom of religion" (93.4\%), "equality of all people under the law" (91.1\%), "human rights, civil liberties and political freedoms" (86.9\%), "rule of law" (82.5\%), "freedom of expression" (80.7\%), "elected political representatives" (77.6\%), "free and independent media" (77.6\%), independent judiciary (76.7\%), and "separation of political and religious authorities" (54.0\%). These findings indicate a strong rejection among Muslim Australians of views that consider Islam and democracy to be incompatible. It should be noted, however, that among Australians in general, support for democracy has been declining. The Democracy 2025 project reported in 2018 that only 40.6 percent of Australians were satisfied with democracy, down from a high of $85.6 \%$ in 2007 (Stoker et al. 2018). According to a 2019 poll conducted by the Lowy Institute (2019), 65 percent of respondents felt that democracy was "preferable to any other form of government", while a study 
conducted by the Australian National University found that 59 percent of participants were satisfied "with the way democracy works in Australia" (Cameron and McAllister 2019).

\subsection{Education}

A final note on education is necessary before moving to the article's discussion. When we compare the survey respondents who possess an undergraduate university degree $(N=279)^{23}$ with those who have not attained a university degree $(N=127)^{24}$ a number of important differences were observed. In relation to typology, respondents with a university degree closely resembled the overall sample, while respondents without a university degree were slightly less likely to be liberal (although still a majority), less likely to be progressive (overall $39.4 \%$; university degree $38.4 \%$; no university degree $28.3 \%$ - although not a significant difference), and more likely to be political Islamist (overall 9.5\%; university degree $8.6 \%$; no university degree $17.3 \%$ ) and militant (overall $3.3 \%$; university degree $2.2 \%$; no university degree $8.7 \%)^{25}$. Specifically concerning political Islam, respondents with a university degree closely aligned with the overall sample, while respondents without a university degree were more likely to say that Islam advocates a particular political system (overall $24.5 \%$; university degree $22.2 \%$; no university degree $32.3 \%$ ) and less likely to say it does not (overall $49.1 \%$; university degree $52.7 \%$; no university degree $33.1 \%)^{26}$. Respondents without a university degree were also less likely to strongly agree that one who attacks civilians is not a martyr (overall $84.4 \%$; university degree $85.7 \%$; no university degree $63.1 \%)^{27}$, although this was not a significant difference. In relation to interpreting the Quran, respondents without a university degree (28.3\%) were more than twice as likely than those who have a university degree (12.2\%) to strongly agree the Quran should be interpreted literally ${ }^{28}$. This is noteworthy, as the issue of reading the Quran literally has been identified in Australian court cases as a factor among terrorism offenders (Rane 2019). Encouragingly, even among those who have not attained a university degree, 85.8 percent consider engaging with non-Muslims as family and friends is good and normal and 85.0 percent are completely or very open to new knowledge about Islam. As an indication of the positive role of higher education in this regard, it is noteworthy that 100 percent of the 279 university graduates said that engaging with non-Muslims as family and friends is good and normal and 87.8 percent are completely or very open to new knowledge about Islam. This will be the focus of a forthcoming article but here we suggest that higher education may be a contributing factor to a more ethical, liberal, progressive understanding of Islam and/or a protective factor against more literalist, politicized, and militant interpretations.

\section{Discussion}

The survey findings represent what 1034 Muslim Australians say about Islam in Australia in a specific time-period. Time-periods refer to the role of historic events in influencing thinking and behavior on an individual basis regardless of one's association with a particular generation or life-cycle

23 This includes respondents who selected "university graduate" as their highest level of education and excludes respondents with post-graduate and $\mathrm{PhD}$ qualification.

24 This includes respondents who selected "in high school", "high school graduate", "started an apprenticeship" and "finished an apprenticeship", and excludes respondents who started or completed a TAFE (college) qualification or stated they are currently "in university".

25 The odds of those without a university degree was not significantly different to the odds of those with a university degree identifying as progressive, $O R=0.640,95 \%$ CIs $[0.403,1.003], p=0.051$. The odds of those without a university degree was $2.226(O R)$ times greater than the odds of those with a university degree identifying as political Islamists, 95\% CIs [1.196, 4.145], $p=0.012$. The odds of those without a university degree was 4.315 (OR) times greater than the odds of those with a university degree identifying as militant, $95 \%$ CIs $[1.556,1.944], p=0.005$.

26 The odds of those without a university degree was $1.669(\mathrm{OR})$ times greater than the odds of those with a university degree believing Islam advocates a particular political system, 95\% CIs [1.046, 2.662], $p=0.032$.

27 The odds of those without a university degree $0.592(O R)$ was not significantly different to the odds of those with a university degree strongly agreeing that those who attack civilians are not martyrs, $95 \%$ CIs [.346, 1.013], $p=0.055$.

28 The odds of those without a university degree was $2.851(\mathrm{OR})$ times greater than the odds of those with a university degree strongly agreeing that the interpretation of the Quran should be literal, 95\% CIs [1.683, 4.828], $p<0.001$. 
phase (Nikolayenko 2008) and provide a useful framework for understanding phenomena related to religious thought and behavior (Rane 2019). The survey respondents resemble the broader Muslim Australian population in relation to key demographic indicators including gender, age distribution, ratio of born in Australia to overseas, ethnic diversity, and employment status. However, there is an over representation of respondents with higher educational qualifications, which is not unusual for complex surveys such as this but should be kept in mind when considering the survey results. Importantly, the survey respondents were largely committed, practicing Muslims for whom Islam is important to their identity. Hence, they were well positioned to respond to this survey. We encourage other researchers to further investigate, but this study suggests that higher education may be a contributing factor to the development of a more ethical, constructive, and peaceful understanding of Islam, and/or a protective factor or counter to legalistic, politicized and militant interpretations of Islam that have been propagated over the past several decades.

Post-9/11, Islam has been seen as a religion that promotes violence and intolerance of non-Muslims, although both these narratives are rejected by the overall findings of this survey. However, this time-period has produced a minority of Muslims who have been seemingly influenced by Islamist political ideologies and Salafist/Wahhabist interpretations that have been propagated since the latter half of the 20th century. Unsurprisingly, some respondents seem to understand and express Islam in legalistic, politicized, and even militant ways, particularly those who may be more vulnerable to radicalization due to grievances with Western military interventions, ${ }^{29}$ and/or the prevalence of anti-Islam sentiments. ${ }^{30}$ This minority of Muslims are represented in this survey, but one should be cautious about making careless assumptions. Even among the 34 respondents who strongly agreed with the statement "I am a committed Muslim who believes an Islamic political order and shariah should be implemented by force if necessary" and were hence classified as "militant", it should not be automatically assumed they pose a threat to others. Almost as many $(38.2 \%)$ in this category defined jihad as defensive $(N=13)$, as offensive $(N=15)$, or were unsure $(N=5)$ about its meaning. A large majority (73.5\%) said "Islam never permits armed conflict against civilians/non-combatants" $(N=25)$, rather than it being permitted "sometimes" $(\mathrm{N}=6)$ or "generally" $(N=3)$. Only 5 of the $34(14.7 \%)$ considered ISIS to be Islamic. Additionally, a large majority strongly agreed (70.6\%) that "someone who dies attacking innocent civilians is not a martyr" (strongly agree $N=24$; agree $N=2$; neither agree nor disagree $N=2$; disagree $N=2$; strongly disagree $N=3$; unsure $N=1$ ). However, respondents in the militant category were likely to have a politicized understanding of Islam with most believing that Islam advocates a particular political system $(N=19,55.9 \%)$ and 73.6 percent agreeing or strongly agreeing that establishing a caliphate is a religious obligation (strongly agree $N=18$; agree $N=7$; neither agree nor disagree $N=2$; disagree $N=2$; strongly disagree $N=2$; unsure $N=3$ ). Encouragingly, militants were more likely than not to believe that "engaging with non-Muslims as family, friends, colleagues and in general social interaction" is good and normal $(N=18,52.9 \%)$ and to be "completely open" ( $N=22)$ or "very open" $(N=7)$ to new knowledge about Islam $(85.3 \%)$. While this indicates the influence of political Islamist and, to a lesser extent, jihadist teachings and propaganda on Muslims in Australia, it also highlights the viable prospects for education about Islam, even among those who might be classified as extreme or militant.

The main rationale of this research is premised on a modest but important idea that wider society's understanding of Islam and Muslims needs to be informed by how Muslim Australians understand, interpret, and express Islam as their lived experience. One of the objectives of the Islam in Australia survey was to address the claims, information, and perceptions that associate Islam and Muslims

29 Among respondents classified as "political Islamist" and "militant", 73.5 percent and 82.4 percent respectively said they were "very concerned" about Australian military interventions in Muslim-majority countries, while 54.2 percent of respondents overall gave this answer.

30 Among respondents classified as "political Islamist" and "militant", 80.6 percent and 88.2 percent respectively said they were "very concerned" about anti-Muslim sentiments, while 71.5 percent of respondents overall gave this answer. 
with militancy, intolerance, misogyny, and alienness so as to contribute to a more objective, informed understanding of Islam and Muslims in Australia. The majority of the survey respondents believe Islam aligns with human rights, civil liberties, and democracy and believe in the rational, cosmopolitan nature of the Islamic tradition based on principles of social justice, gender justice, and religious pluralism. What many seem to mean by this is an understanding of Islam that involves prioritizing the spirit and ethical principles of Islam over heavily textualist, legalistic, and politicized interpretations. Respondents' strongest social connections were found to be with family, which was also an important source of influence in terms of their understanding of Islam (along with imams, sheikh, ulema, and academic scholars), while the Qur'an was by far the most important source of influence.

Acts of violent extremism and terrorism have often been conducted in the name of Islam due to inadequate or misleading religious instruction, including misinterpretation of the Qur'an. How the Qur'an is interpreted by Muslims is an important question that has been raised in Australia and elsewhere in media and political discourses as well as in Australian courts in relation to terrorism offenders (Rane 2019). In the case of R v. Khaja in 2018, Justice Desmond Fagan raised a valid question about how Muslims interpret the Qur'an and called for "cogent religious instruction that the verses upon which he [Khaja] relied are cancelled and that killing non-Muslims and destruction of democratic government are not decreed by Allah" (see Rane 2019, p. 5). The Islam in Australia survey results show that respondents prefer contextual and maqasid-oriented approaches to interpreting the Qur'an over textualist and literalist approaches. Accordingly, survey findings demonstrate that respondents hold a compassionate, progressive, and tolerant understanding of Islam that prioritizes Islamic values of wellbeing (maslaha) and social justice understood as ethically objectivist concepts and values not wedded to a textualist hermeneutic. Furthermore, interpretations of Islam that advocate violence and intolerance towards non-Muslims seem to resonate with only a minute number of individuals according to the survey's findings. The overwhelming majority of Muslim Australians do not read or interpret the Qur'an in ways that condone violent extremism. In this respect, our results indicate that problems with how Muslims interpret the Qur'an exist among a minority rather than the mainstream majority. Moreover, while there is a minority of Muslim Australians who have been influenced by politicized and militant views derived from literalist and/or heavily textualist interpretations, the very high degree of openness to new knowledge among Muslim Australians suggests that education programs have a good chance of succeeding. This finding emphasizes the important role of Islamic scholars and teachers, supported by government and community organizations, in this space.

Perhaps due to the high level of heterogeneity and diversity of Australia's Muslim communities in multiple respects, the legitimacy of more than one interpretation of Islam was widely acknowledged by the survey respondents. This runs contrary to the monolithic, narrow, and superficial understanding of Islam that we generally find apparent in pejorative media, political, and public discourses on Islam and Muslims (Rane et al. 2014). The survey showed that Muslim Australians overwhelmingly align their faith with principles of equality, social justice, human rights, animal welfare, and environmental sustainability. They express deep concern for a range of social issues that impact society as a whole, including domestic violence, mental health, affordable housing, treatment of asylum seekers, climate change, terrorism by Muslim extremists, affordable higher education, economic inequality, Australian military intervention in Muslim-majority countries, unemployment, and reconciliation with indigenous Australians, as well as issues that have an impact on Muslims in particular, namely media reporting on Islam and Muslims, discrimination against Muslims, anti-Islam sentiments, and terrorism by right-wing extremists. The vast majority of survey respondents are content with the extent to which Muslims are currently able to practice Islam in Australia, agree that Australia's legal system upholds the principles of justice, and do not believe that countries today that implement classical shariah laws are more just and fair than Australia. These views extend to the way Muslim Australians regard Muslim-majority countries and their preference for more democratic, open, and tolerant nations over authoritarian, closed, and intolerant ones, even though countries in the latter category, namely Saudi Arabia and Iran, proclaim themselves as "Islamic" nations. Additionally, in regard to the dominant stereotype that 
associates Islam and Muslims with violence and intolerance of non-Muslims, the overwhelming majority of respondents completely reject the notion that violence against innocent civilians is encouraged or condoned by Islam.

The survey also identified important avenues for addressing national security concerns. At the time of writing, national security concerns are shifting toward a focus on the threat of violent extremism from the far-right (ASIO 2020). As the cases of Brenton Tarrant, Anders Breivik, and others confirm, what non-Muslims think about Islam also matters. Their acts of terrorism targeted Muslims out of a fear that the presence of Muslims in Western countries poses an existential threat to non-Muslims (Ebner 2017). The Islam in Australia survey addressed fundamental questions about Islam and Muslims in Australia and its findings should also be incorporated into programs aiming to counter violent extremism among the far-right. More generally, it is hoped that these findings will contribute to an understanding - contrary to sensational media reporting, Islamist-jihadist propaganda, and uninformed commentary - that an authentic, ethical, progressive, and peaceful Islam that teaches respectful coexistence with non-Muslims is not only theoretically possible but that it is generally exemplified in the lived experiences of Muslims in 21st century Australia.

Part of overcoming prejudice, racism, and Islamophobia is for society to develop more objective, informed, and authentic insights into the communities and groups in question. Muslims have been part of Australia's story prior to British settlement and have peacefully coexisted and contributed to Australia's success as a multicultural country. While Muslims began to appear on the media and public radar in the late 1980s as a group inclined towards religious fanaticism, the framing of Islam and Muslims as a threat to national security did not become dominant until after 11 September 2001 (Rane et al. 2014). Around the time Australia appeared to be moving on from 9/11 (Ewart and Rane 2011), national and international attention became captivated by uprisings in the Middle East and North Africa calling for freedom and democracy (Rane and Salem 2012). Hopes for the region were overshadowed, however, by the rise of militant groups, particularly ISIS, which actively recruited Muslims from around the world, including Australia, to join its ranks and conduct acts of terrorism. Although relatively small in number and unrepresentative of Islam and Muslim populations more broadly, ISIS and its supporters confirmed fears of an Islamic threat (Esposito 1999), an inevitable clash of Islamic and Western civilizations (Huntington 1993), and even a great replacement of non-Muslims by Muslims (Berwick 2011). This survey's findings show that the vast majority of Muslim Australians believe Islam teaches peaceful, respectful coexistence with non-Muslims. For this to be recognized by wider Australian society is important given the threat posed by the far-right to social cohesion and national security (ASIO 2020). The most challenging form of Islamophobia, which hopefully this research will help address, is that which refuses to acknowledge an ethical, peaceful, progressive Islam as authentic Islam (Duderija 2017).

This study has several strengths and limitations. It utilized the far-reaching potential of sampling online, including through social media, augmented by the assistance of Australian Muslim organizations, groups, and representatives to sample Australia's diverse Muslim communities. While a potentially large number of Muslims became aware of this study, it is inevitable that some did not, despite this sampling strategy. These could include individuals who are disconnected from other Muslims and/or internet communications technology. Participation in this research was based on self-selection with no incentives. Combined with the assurance of anonymity, this fosters greater confidence that responses were genuine. However, because participants opted to complete the survey voluntarily, views may not be completely representative of the entirety of Australia's diverse Muslim communities. There may be a greater representation of Muslims strongly connected to their Muslim identity or with views they wish to share. Conversely, there would likely be Muslim Australians who declined to participate because they found the questions too complex, intrusive, or confronting, or were otherwise unwilling to share their views, which they may perceive to be at odds with other Muslim Australians and/or wider society. Further, notwithstanding that 8 in 10 Muslim Australians are proficient in the English language (Hassan 2015), those not proficient in English would not have participated. 
Also, being a lengthy survey, the potential that participants experienced fatigue toward the end of its duration is possible. However, the final segment of the survey posed optional open-ended questions, suggesting the preceding quantitative questions may not have been greatly affected by fatigue. These considerations suggest findings stemming from the survey are valid. In saying this, we encourage other researchers to utilize the survey questions (Appendix A) to conduct further research on Islam in Australia and the West more generally.

\section{Conclusions}

This article has outlined key findings from the 2019 Islam in Australia survey, which gives considerable insight into the beliefs, identities, and experiences of Muslim Australians. Overall, the findings of this research suggest that stereotypical constructions of Islam and Muslims that have proliferated in mass media and political discourse over the past two decades are not consistent with the beliefs and lived realities of the vast majority of Muslim Australians. Rather, Muslim Australians, while highly diverse, overwhelmingly display an understanding and identify with interpretations of Islam that value equality, human rights, social cohesion, and social justice and reject violence and intolerance. However, a minority of respondents seemingly understand and interpret Islam in ways that reflect the influence of late 20th and early 21st century ideas associated with Islamist political ideology. While a much smaller group was found to hold views classified as militant, these do not necessarily translate into acceptance of violence against civilians. Even among this latter group, most also believe that Islam never permits armed conflict against civilians/non-combatants and the overwhelming majority believe that someone who dies attacking innocent civilians is not a martyr. While they are more likely than other Muslim Australians to believe the Qur'an should be interpreted literally and on the basis of a highly textualist hermeneutic, many are also open to contextual and maqasid-oriented interpretations and recognize that some verses of the Qur'an are specific to the time and circumstances of the Prophet Muhammad. Their main points of difference with the majority of Muslim Australians is their higher than average adoption of Islamist political ideology, including a belief that Islam advocates a particular political system and that establishing a caliphate is a religious obligation. However, within this group as well as the respondents overall, the survey found considerable uncertainty in relation to questions pertaining to political Islam, as expressed through respondents' selection "unsure/I don't know". This highlights the need for further information and education, particularly concerning the principles and values of Islam, its teachings concerning social relations, and the modern history of idea associated with political Islam. It is also evident that Muslim Australians continue to be concerned about acceptance and their place within broader Australian society, with negative media representation and discrimination against Muslims remaining as significant points of unease. During a time-period in which misinformation about Islam and Muslims continues to abound, it is hoped that this research will contribute to a more informed and nuanced understanding of how Islam is actually understood, experienced, and expressed by Muslim Australians today.

Author Contributions: Conceptualization, H.R., A.D., P.M. and S.S.; methodology, H.R., R.H.R. and J.M.; validation, R.H.R.; formal analysis, H.R., R.H.R. and J.M.; investigation, H.R., P.M., S.S., J.M. and A.D.; data curation, H.R., R.H.R., J.M. and S.S.; writing-original draft preparation, H.R.; writing-review and editing, H.R., P.M., J.M., A.D., R.H.R. and S.S.; visualization, H.R., P.M. and J.M.; supervision, H.R.; project administration, H.R. and P.M. All authors have read and agreed to the published version of the manuscript.

Funding: This research received no external funding.

Conflicts of Interest: The authors declare no conflict of interest. 


\section{Appendix A. Survey Questions}

Appendix A.1. Section A: Preliminary

This survey is intended for Muslim participants who are either Australian citizens or permanent residents.

A1. For participants over 18 years of age, please check the box below to indicate your consent to participate.

For participants under 18 years of age, you and your parent or guardian will need to check the relevant boxes below to participate.

Expression of consent

I have read the information on the consent form or someone has read it to me. I agree to take part in this survey and give my consent freely. I understand that whether or not I decide to participate is my decision. I understand that I can withdraw from the survey at any time and that I do not have to give any reasons for doing this.

I understand the risks involved; I understand that I am free to withdraw at any time, without explanation or penalty; I understand that if I have any additional questions I can contact the research team; I understand that my name and other personal information that could identify me will be removed or de-identified in publications or presentations resulting from this research; I understand that there will be no direct benefit to me from my participation in this research; I understand that I can contact the Manager, Research Ethics, at Griffith University Human Research Ethics Committee on 37354375 (or research-ethics@griffith.edu.au) if I have any concerns about the ethical conduct of the research (Ethics Reference Number: 2019/042).

I agree to participate in the survey

If applicable, I agree as a parent or guardian for my dependant to participate

\section{A2. Do you identify as a Muslim?}

\section{Yes/No}

\section{A3. Are you an Australian citizen or permanent resident?}

Yes/No

Appendix A.2. Section B: Demographic

These questions will allow us to check that this survey is representative of the Australian Muslim population in regards to age, gender, geographical location, country of origin, education level and employment status of participants.

B1. What is your current age?

B2. What is your gender?

Female/Male/Other

B3. What is your postcode?

B4. In which country or countries were you raised?

B5. Were you born in Australia or overseas? 
Born in Australia/Born overseas

B6. When did your first family members arrive in Australia?

After the year 2000

1980s-1990s

1960s-1970s

1940s-1950s

Before the 1940s

Unsure

B7. When did you arrive in Australia?

After the year 2000

1980s-1990s

1960s-1970s

1940s-1950s

Before the 1940s

B8. What ethnicity, nationality or cultural group do you most identify with?

B9. What is your highest level of education?

In High School

High School Graduate

At TAFE

TAFE Graduate

Started Apprenticeship

Finished Apprenticeship

In University

University Graduate

In Post-Graduate Study

Post-Graduate

In a PhD Program

PhD Graduate

B10. As a high school student, which of the following fields of education are/were you most interested in?

Fine Art (music, painting, drama, etc.)

Arts and Humanities (philosophy, history, literature, communications, languages, etc.)

Islamic Studies

Social Science (anthropology, sociology, psychology, etc.)

Law/Legal studies

Education/Teaching

Business/Economics (commerce, accounting, etc.)

Engineering

Health/Medicine

Science (astronomy, biology, chemistry, physics, etc.)

Mathematics

Information Technology (IT)

Other 
B11. If you have a TAFE diploma, in what field did you receive your diploma?

B12. If you have an apprenticeship or trade, what are you currently in training for or qualified in?

B13. If you are currently at university or completed a university degree, in what field of study are you currently enrolled or have completed a degree?

Fine Art (music, painting, drama etc.)

Arts and Humanities (philosophy, history, literature, communications, languages, etc.)

Islamic Studies

Social Science (anthropology, sociology, psychology, etc.)

Law/Legal studies

Education/Teaching

Business/Economics (commerce, accounting, etc.)

Engineering

Health/Medicine

Science (astronomy, biology, chemistry, physics, etc.)

Mathematics

Information Technology (IT)

Other

B14. Which of the following best describes your current employment status?

Full-time

Part-time

Casual

Student

Self-employed

Volunteer

Not currently employed

Retired

Other

Appendix A.3. Section C: Conversion

These questions will allow us to have a better understanding of the number of participants who are born Muslims and those who have converted/reverted to Islam.

C1. Were you born/raised a Muslim or did you convert/revert to Islam?

Born/Raised Muslim

Converted/Reverted to Islam

C2. At what age did you become Muslim?

C3. What were the most important factors in your life, or aspects of Islam, that led you to convert/revert to Islam?

Personal hardship

Death of a relative or friend

Spiritual awakening

Answers to questions concerning the purpose of life

Message of the Qur'an 
Example of the Prophet Muhammad (pbuh)

Personal connection with a Muslim

Marriage to a Muslim

Disaffection or disillusion with a previous faith

Sense of community/belonging

Other

C4. When you were considering converting/reverting, which teachings or aspects of Islam, if any, did you have reservations about or find problematic?

No issues or problems

Views about non-Muslims

Views about women

Views about homosexuals

Views about violent jihad

Mixing religion with politics

Terrorism in the name of Islam

Gender segregation

Dietary requirements

Other

C5. Which Islamic tradition, school of thought or group, if any, did you most identify with when you first converted/reverted to Islam?

\section{C6. How has your understanding or practice of Islam evolved since you converted/reverted?}

C7. Since converting/reverting to Islam, to what extent have you experienced difficulties with the following?

[A great deal of difficulty/Some difficulty/Very little/No difficulty/Not applicable]

Gaining authentic knowledge about Islam

Reactions or attitudes of family and friends

Reactions from the general Australian public

Making Muslim friends

Acceptance from the local Muslim community

Locating support networks for converts/reverts

Attitudes towards the opposite sex

Gender segregation

Understanding the Qur'an

Understanding the hadith

Learning how to perform acts of worship

Muslim cultural beliefs or practices

Dietary requirements

Appendix A.4. Section D: Identity

These questions are about your identity as a Muslim.

\section{D1. How important is Islam to your identity?}

Very important

Important 
Not very important

Not at all important

D2. With which Islamic tradition, school of thought or group do you most identify?

Just Muslim

Sunni

Ahl Sunnah wal Jamaa

Shia/Shiite

Ibadi

Sufi

Hanafi

Maliki

Shafi'i

Hanbali

Ja'fari

Ismaili

Zaydi

Ahl-Qur'an

Ahl-Hadith

Salafi

Muwahhidun (Wahhabi)

Tabligh Jamaat

Hizb ut-Tahrir

Progressive

Other

D3. Which of the following best describes how you identify as a Muslim?

I publicly/openly identify as a Muslim

I identify as Muslim within Muslim communities only

I share my identity as Muslim with friends/family only

I consider my identity as a Muslim to be a private, personal matter

D4. How frequently do you pray (perform salat/namaz)?

Daily

Weekly

Monthly

Only on occasions

Never

D5. Please rate the following statements according to how well they describe you as a Muslim.

[Strongly agree/Agree/Neither agree nor disagree/Disagree/Strongly disagree/Unsure]

I am a cultural Muslim for whom Islam is based on my family background rather than my practice For me Islam is a matter of personal faith rather than a public identity

I believe Islam aligns with human rights, civil liberties and democracy

I am a devout Muslim who follows a more spiritual path rather than formal legal rules

I am a committed, reform-minded Muslim who emphasizes the spirit and ethical principles of Islam over literal interpretations 
I am a committed Muslim who believes in the rational, cosmopolitan nature of the Islamic tradition based on principles of social justice, gender justice and religious pluralism

I am a devout Muslim who follows a traditional understanding of Islam

I am a strict Muslim who follows Islam according to the laws of shariah

I am a committed Muslim who believes politics is part of Islam and advocates for an Islamic state based on shariah laws

I am a committed Muslim who believes an Islamic political order and shariah should be implemented by force if necessary

D6. To what extent do you feel judged by other Muslims in relation to your understanding and practice of Islam?

All the time

A lot

Sometimes

Rarely

Never

Appendix A.5. Section E: Sources of Information

These questions are about your sources of information for understanding Islam.

E1. How influential are the following sources for your current understanding of Islam?

[Very influential/Somewhat influential/Not very influential/Not at all influential/N/A]

Family

Friends

Imams/Sheikhs/Ulema

Mosque/Madrassa classes

School

University

Academic scholars

The Qur'an

Hadith

Scholarly books

Internet (websites, forums, YouTube, etc.)

Social media (Facebook, Twitter, etc.)

E2. If you were to recommend one source of information to someone wanting to understand Islam, what would that be? For example, a person, group, book, or website, etc.

E3. Which of the following best describes your confidence that what you have learnt about Islam is true and accurate?

Completely confident

Very confident

Somewhat confident

Not very confident

Not at all confident

E4. Which of the following best describes your views on receiving new knowledge about Islam?

Completely open to new knowledge 
Very open to new knowledge

Somewhat open to new knowledge

Not very open to new knowledge

Not at all open to new knowledge

Appendix A.6. Section F: Understanding and Interpreting

These questions concern your views on how Islam should be understood and interpreted.

F1. In general, when you have a question that relates to Islam, which of the following sources are you most likely to consult for guidance?

The Qur'an

Hadith

Qur'an and Hadith

Classical Islamic schools of thought (madhahib) (e.g., Hanafi, Hanbali, Jafari, Maliki, Shafi'i, Zaydi, etc.)

Contemporary traditional Islamic scholars (e.g., Hamza Yusuf, Nasir al-Albani, Taqi Uthmani, Yusuf Qaradawi, etc.)

Contemporary progressive Islamic scholars (e.g., Abdullah Saeed, Amina Wadud, Khaled Abou El-Fadl, Mohammad Hashim Kamali, etc.)

Unsure

Other

F2. To what extent do you agree or disagree with the following statements?

[Strongly Agree/Agree/Neither Agree nor Disagree/Disagree/Strongly Disagree/Unsure]

Women should be given the same rights and opportunities as men

Marriage should be based on mutual respect rather than the subservience of one spouse to the other People of all religions and no religion should be treated equally

Abiding by Australian laws does not equate to disobedience to Allah

Taking the citizenship pledge (in the name of God) equates to a religiously-binding oath

Indigenous people should be recognized in Australia's constitution

Environmental sustainability should be given higher priority in Islamic discourse

Halal certifiers should assess the ethical treatment of animals as part of the halal certification process There needs to be more emphasis on Islamic ethics rather than jurisprudence when teaching Islam Someone who dies attacking innocent civilians is not a martyr (shaheed)

F3. Which of the following best describes your view on how Islam should be understood?

There is only one valid interpretation

There are few valid interpretations

There are many valid interpretations

There are potentially as many valid interpretations as there are Muslims

Unsure

F4. To what extent do you agree or disagree with the following statements regarding the reading and interpreting of the Qur'an?

[Strongly Agree/Agree/Neither Agree nor Disagree/Disagree/Strongly Disagree/Unsure]

The Qur'an should be read and interpreted literally

All verses of the Qur'an apply to all time, place and circumstances 
Some verses of the Qur'an are specific to the Prophet Muhammad's time and circumstances while others are relevant to all times and places

The Qur'an should be read and interpreted contextually in relation to historic and social contexts

The Qur'an should be read and interpreted in relation to the principles (maqasid) of Islam

The Qur'an should be understood according to the interpretations of classical scholars only

The Qur'an should be understood according to the interpretations of classical and contemporary scholars

The Qur'an allows for new interpretations in response to changing conditions and realities

Appendix A.7. Section G: Issues

These questions concern your views on legal and political issues in relation to Islam.

G1. What is your understanding of the term jihad according to how it is used in the Qur'an and in the example of the Prophet Muhammad (pbuh)?

To strive/struggle through spiritual, charitable or good deeds, including armed struggle in self-defence only

To strive/struggle through spiritual, charitable or good deeds, including defensive and offensive armed struggle

Don't know/Unsure

Other

G2. In relation to armed conflict, what is your understanding of how Islam regards civilians/non-combatants?

Islam never permits armed conflict against civilians/non-combatants

Islam sometimes permits armed conflict against civilians/non-combatants

Islam generally permits armed conflict against civilians/non-combatants

Don't know/Unsure

G3. Do you believe that Islam advocates a particular political system?

Yes/No

Don't know/Unsure

G4. Which of the following do you consider to be legitimate Islamic states? You may also give another example of a state or political system you consider to be legitimately Islamic.

Kingdom of Saudi Arabia

Islamic Republic of Iran

Islamic Republic of Pakistan

Islamic State of Iraq and Syria (ISIS, ISIL, Daesh)

Other

G5. Is Islam compatible with the principles of democracy?

Yes, completely

Mostly

Not very

No, not at all

Don't know/unsure

G6. To what extent do you agree or disagree with the following principles of democracy?

[Strongly Agree/Agree/Neither Agree nor Disagree/Disagree/Strongly Disagree/Unsure] 
The rule of law

Equality of all people under the law

Elected political representatives

Independent judiciary

Separation of political and religious authorities

Human rights, civil liberties, and political freedoms

Freedom of religion

Freedom of expression

Free and independent media

G7. To what extent do you agree or disagree that the form of government referred to as a khilafah/caliphate is an Islamic religious obligation?

[Strongly Agree/Agree/Neither Agree nor Disagree/Disagree/Strongly Disagree/Unsure]

G8. Which of the following is closest to your understanding of the term shariah?

The divine/revealed law/legal code

Islamic jurists' opinions and interpretations based on the Qur'an and other sources

Don't know/unsure

Other

Other

G9. To what extent do you agree or disagree with the following statements about Islam and classical shariah laws in relation to Australian laws and legal system?

[Strongly Agree/Agree/Neither Agree nor Disagree/Disagree/Strongly Disagree/Unsure] I am content with the extent to which Muslims are currently able to practice Islam in Australia Australia's legal system upholds principles of justice and I am generally satisfied with it I would like classical shariah laws relating to family matters, such as marriage, divorce and inheritance, recognized in Australian law

I would like to live in a country where polygamy (polygyny: a man marrying multiple women) is legal I would like to live in a country where classical shariah punishments are implemented Countries today that implement classical shariah laws are more just and fair than Australia

Appendix A.8. Section H: Social Connection

These questions ask about your feelings of acceptance, sense of belonging and social connections.

H1. In relation to the following social groups/contexts, how strongly do you feel involved, connected and a sense of belonging?

[Very strong/Strong/Moderate/Weak/Very weak/Unsure/Not applicable]

Family and friends

Neighborhood

Local mosque

Muslim community

School, university or workplace

Sports, recreation or other clubs

Wider Australian society

Australian political system

H2. Are you affiliated with any Islamic/Muslim organization such as an association, council, committee, federation, group, movement, society, etc.? 
Yes/No

H3. With which Islamic/Muslim organization, association, council, committee, federation, group, movement or society are you affiliated?

H4. Which of the following statements is closest to what you think about engaging with non-Muslims as family, friends, colleagues and in general social interactions?

Engaging with non-Muslims is normal and good

Engaging with non-Muslims should be primarily done for da'wah (to spread Islam)

Engaging with non-Muslims is discouraged in Islam and should be kept to a minimum

Engaging with non-Muslims is forbidden in Islam and should be avoided

Don't know/unsure

H5. To what extent do you agree that your freedom to practice Islam is threatened in Australia?

[Strongly Agree/Agree/Neither Agree nor Disagree/Disagree/Strongly Disagree/]

H6. If you think your freedom to practice Islam is threatened in Australia, please specify why you think so:

H7. How concerned are you about the following issues?

[Very concerned/Concerned/Not very concerned/Not at all concerned/Unsure]

Climate change

Reconciliation with indigenous Australians

Treatment of asylum seekers

Economic inequality

Unemployment

Affordable higher education

Affordable housing

Domestic violence

Mental health

Anti-Islam sentiments

Discrimination against Muslims

Media reporting on Islam and Muslims

Terrorism by right-wing extremists

Terrorism by Muslim extremists

Australian military intervention in Muslim-majority countries

H8. How trustworthy do you consider the following social institutions and policies in performing their functions effectively, fairly and honestly?

[Very trustworthy/Somewhat Trustworthy/Not very trustworthy/Not at all Trustworthy/Unsure]

Parliament

Judiciary (courts)

Defence forces (military)

Security/Intelligence agencies

Law-enforcement agencies (police)

Australian Federation of Islamic Councils (AFIC)

State Islamic Council

State board of Imams

National board of Imams 
Islamic schools/colleges

Public schools

Multicultural policy

Counter-terrorism policy

Countering violent extremism policy (CVE)

Border protection policy

Appendix A.9. Section I: Representation

These questions concern your views about how Islam is represented.

I1. In your opinion, what impact have the following countries had on the understanding and practice of Islam among Muslims in general over the past few decades?

[Very Positive/Positive/Neutral/Negative/Very Negative/Unsure]

Egypt

Indonesia

Iran

Malaysia

Morocco

Pakistan

Qatar

Saudi Arabia

Turkey

I2. Among the various countries, groups and individuals in the world, which/who do you think best upholds the values of Islam as you understand them?

Country

Group

Individual (person)

I3. Briefly, in your own words, which verse of the Qur'an, Hadith or story from Islamic tradition best represents your understanding of what it means to be a Muslim?

I4. How would you describe the main teachings of Islam to a non-Muslim?

I5. Do you have any additional comments or feedback about this survey?

\section{References}

Akyol, Mustafa. 2019. A New Secularism Is Appearing in Islam. New York Times. December 23. Available online: https://www.nytimes.com/2019/12/23/opinion/islam-religion.html? fbclid=IwAR1rkSyevrtcDoSnRJWZznUNE3OSB8lj4HJW8ga8izPPF8fHEXbhyi12vfI\#click=https: //t.co/4vSnAwCBK5 (accessed on 30 June 2020).

Al-Dawoody, Ahmed. 2011. The Islamic Law of War: Justifications and Regulations. New York: Palgrave Macmillan. Anjum, Ovamir. 2016. Salafis and Democracy: Doctrine and Context. The Muslim World 106: 448-73. [CrossRef] ASIO (Australian Security Intelligence Organisation). 2020. Director-General's Annual Threat Assessment. February 24. Available online: https://www.asio.gov.au/director-generals-annual-threat-assessment.html (accessed on 30 June 2020).

Australian Bureau of Statistics. 2018. Census of Population and Housing: Reflecting Australia-Stories from the Census, 2016: ‘Religion'. Available online: https://www.abs.gov.au/AUSSTATS/abs@.nsf/DetailsPage/ 2071.02016? OpenDocument (accessed on 30 June 2020). 
Australian National Security. 2019. National Terrorism Threat Advisory System. Available online: https://www.nationalsecurity.gov.au/Securityandyourcommunity/Pages/National-Terrorism-ThreatAdvisory-System.aspx (accessed on 30 June 2020).

Australian Psychological Society. 2018. Australian Loneliness Report: A Survey Exploring the Loneliness Levels of Australians and the Impact on Their Health and Wellbeing. Available online: https:/psychweek.org.au/ 2018-archive/loneliness-study/ (accessed on 30 June 2020).

Bayat, Asef, ed. 2013. Post-Islamism: The Changing Faces of Political Islam. New York: Oxford University Press.

Berwick, Andrew. 2011. 2083: A European Declaration of Independence. Available online: https://info. publicintelligence.net/AndersBehringBreivikManifesto.pdf (accessed on 30 June 2020).

Bouma, Gary D. 1994. Mosques and Muslim Settlement in Australia. Canberra: Australian Government Publishing Service.

Bouma, Gary D. 1995. The Emergence of Religious Plurality in Australia: A Multicultural Society. Sociology of Religion 56: 285-302. [CrossRef]

Cameron, Sarah, and Ian McAllister. 2019. The 2019 Australian Federal Election: Results from the Australian Election Study. Canberra: Australian National University, Available online: https://australianelectionstudy.org/wp-content/uploads/The-2019-Australian-Federal-ElectionResults-from-the-Australian-Election-Study.pdf (accessed on 10 June 2020).

Chilcot, John. 2016. The Iraq Inquiry. Available online: https://webarchive.nationalarchives.gov.uk/ 20171123122743/http://www.iraqinquiry.org.uk/the-report/ (accessed on 15 June 2020).

Ciftci, Ayse, Nev Jones, and Patrick Corrigan. 2013. Mental Health Stigma in the Muslim Community. Journal of Muslim Mental Health 7: 17-32. [CrossRef]

Curtin, Richard, Stanley Presser, and Eleanor Singer. 2000. The effects of response rate changes on the index of consumer sentiment. Public Opinion Quarterly 64: 413-28. [CrossRef]

Dean, Geoff, Peter Bell, and Zarina Vakhitova. 2016. Right-wing extremism in Australia: The rise of the new radical right. Journal of Policing, Intelligence and Counter Terrorism 11: 121-42. [CrossRef]

Duderija, Adis, and Halim Rane. 2019. Islam and Muslims in the West. New York: Palgrave Macmillan.

Duderija, Adis. 2017. The Imperatives of Progressive Islam. New York: Routledge.

Dunn, Kevin M., Natascha Klocker, and Tanya Salabay. 2007. Contemporary racism and Islamophobia in Australia racializing religion. Ethnicities 7: 564-89. [CrossRef]

Dunn, Kevin, Rosalie Atie, and Virginia Mapedzahama. 2016. Ordinary cosmopolitans: Sydney Muslims' attitudes to diversity. Australian Geographer 47: 281-94. [CrossRef]

Ebner, Julia. 2017. The Rage: The Vicious Circle of Islamist and Far-Right Extremism. London: Bloomsbury.

The Environics Institute for Survey Research. 2016. Survey of Muslims in Canada 2016. Available online: https://www.environicsinstitute.org/docs/default-source/project-documents/survey-of-muslimsin-canada-2016/final-report.pdf?sfvrsn=fbb85533_2 (accessed on 16 June 2020).

Esposito, John. 1999. Islamic Threat: Myth or Reality. Oxford: Oxford University Press.

Esposito, John, and Dalia Mogahed. 2007. Who Speaks for Islam: What a Billion Muslims Really Think. New York: Gallup Press.

Essential Research. 2016. Ban on Muslim Immigration. Essential Report. Available online: https://www. essentialvision.com.au/ban-on-muslim-immigration (accessed on 21 June 2020).

Essential Research. 2019. The Essential Report: 27 June 2019. Available online: https://www.essentialvision.com. au/wp-content/uploads/2019/06/Essential-Report-280619.pdf (accessed on 21 June 2020).

Ewart, Jacqui, and Halim Rane. 2011. Moving on from 9/11: How Australian television reported the ninth anniversary. Journal of Media and Religion 10: 55-72. [CrossRef]

Farooq, Mohammad Omar, and Nedal El-Ghattis. 2018. In Search of the Shari'ah. Arab Law Quarterly 32: 315-54. [CrossRef]

Ganter, Regina. 2008. Muslim Australians: The deep histories of contact. Journal of Australian Studies 32: 481-92. [CrossRef]

Gleeson, Hayley, and Julia Baird. 2017. Exposing the Darkness within: Domestic Violence and Islam. ABC News. Available online: https://www.abc.net.au/news/2017-04-24/confronting-domestic-violence-in-islam/8458116? nw $=0$ (accessed on 7 August 2020).

Goli, Marco, and Shahamak Rezaei. 2011. Radical Islamism and Migrant Integration in Denmark: An Empirical Inquiry. Journal of Strategic Security 4: 81-114. [CrossRef] 
Goyder, John. 1986. Surveys on surveys: Limitations and potentialities. Public Opinion Quarterly 50: $27-41$. [CrossRef]

Goyder, John, Keith Warriner, and Susan Miller. 2002. Evaluating socio-economic status (SES) bias in survey nonresponse. Journal of Official Statistics 18: 1-11.

Greene, Andrew. 2019. 'We clearly failed in Afghanistan': Confidential files show public was 'lied to' about Afghan war. AM, Australian Broadcasting Authority. December 11. Available online: https://www.abc.net.au/ radio/programs/am/confidential-files-show-public-was-mislead-about-afghan-war/11787238 (accessed on 30 June 2020).

Groves, Robert M., Eleanor Singer, and Amy Corning. 2000. Leverage-saliency theory of survey participation. Public Opinion Quarterly 64: 299-308. [CrossRef]

Hallaq, Wael. 2009. Shari'a: Theory, Practice, Transformations. Cambridge: Cambridge University Press.

Hassan, Riaz. 2015. Australian Muslims: A Demographic, Social and Economic Profile of Muslims in Australia 2015. Available online: https://www.unisa.edu.au/siteassets/episerver-6-files/global/eass/mnm/publications/ australian_muslims_report_2015.pdf (accessed on 16 July 2020).

Hassan, Riaz, and Bill Martin. 2015. Islamophobia, Social Distance and Fear of Terrorism in Australia: A Preliminary Report. Adelaide: International Centre for Muslim and non-Muslim Understanding, University of South Australia, Available online: https:/www.unisa.edu.au/siteassets/episerver-6-files/global/eass/mnm/ publications/islamophobia_report.pdf (accessed on 31 October 2019).

Howell, Sally. 2014. Old Islam in Detroit: Rediscovering the Muslim American Past. Oxford: Oxford University Press. Humphrey, Michael. 2001. An Australian Islam? Religion in the multicultural city. In Muslim communities in Australia. Sydney: University of New South Wales Press, pp. 33-52.

Huntington, Samuel. 1993. The Clash of Civilizations? Foreign Affairs 72: 22-49. [CrossRef]

Iner, Derya. 2019. Islamophobia in Australia - II (2016-2017). Bathurst: Centre for Islamic Studies and Civilisations, Charles Sturt University, Available online: http:/www.islamophobia.com.au/wp-content/uploads/2019/11/ Islamophobia-Report-2019-2.pdf (accessed on 30 June 2020).

Jenkins, Nash. 2014. You'll Never Guess Which Country Is the Biggest Per Capita Contributor of Foreign Jihadists to ISIS. Time. June 23. Available online: http://time.com/2911040/australia-isis-syria-iraq-terrorism/ (accessed on 30 June 2020).

Johnson, Shonteria L., Noah D. Drezner, Jason C. Garvey, and Michael Bumbry. 2016. Social Media Use for Survey Distribution. In Academics Going Public: How to Write and Speak Beyond Academe. Edited by Marybeth Gasman. New York: Routledge, pp. 87-103.

Jones, Mary Lucille. 1993. An Australian Pilgrimage: Muslims in Australia from the Seventeenth Century to the Present. Melbourne: Victoria Press.

Kamali, Mohammad Hashim. 2006. Introduction to Shariah. Kuala Lumpur: Ilmiah.

Kandel, Denise, Victoria Raveis, and John Logan. 1983. Sex differences in the characteristics of members lost to a longitudinal panel: A speculative research note. Public Opinion Quarterly 47: 567-75. [CrossRef]

Knaus, Christopher, Michael McGowan, Nick Evershed, and Oliver Holmes. 2019. Inside the Hate Factory: How Facebook Fuels Far-Right Profit. The Guardian. Available online: https://www.theguardian.com/australianews/2019/dec/06/inside-the-hate-factory-how-facebook-fuels-far-right-profit (accessed on 11 January 2020).

Kull, Steven. 2007. Muslim Public Opinion on US Policy, Attacks on Civilians and al Qaeda. College Park: World Public Opinion, Available online: http://worldpublicopinion.net/wp-content/uploads/2019/12/START_Apr07_rpt. pdf (accessed on 20 May 2020).

Larsson, Göran. 2012. The Fear of Small Numbers: Eurabia Literature and Censuses on Religions Belonging. Journal of Muslims in Europe 1: 142-65. [CrossRef]

Laurence, Jonathan. 2012. The Emancipation of Europe's Muslims: The State's Role in Minority Integration. Princeton: Princeton University Press.

Lowy Institute. 2019. Lowy Institute Poll 2019: Democracy. Available online: https://lowyinstitutepoll. lowyinstitute.org/themes/democracy/ (accessed on 30 July 2020).

Mahood, Samantha, and Halim Rane. 2017. Islamist Narratives in ISIS Recruitment Propaganda. Journal of International Communication 23: 15-35. [CrossRef]

March, Andrew. 2011. Islam and Liberal Citizenship: The Search for an Overlapping Consensus. Oxford: Oxford University Press. 
Markus, Andrew. 2018. Mapping Social Cohesion. The Scanlon Foundation Surveys 2018. Melbourne: ACJC Monash University, Available online: https://scanlonfoundation.org.au/wp-content/uploads/2018/12/Social-Cohesion2018-report-26-Nov.pdf (accessed on 31 October 2019).

Means, Gordon. 2009. Political Islam in Southeast Asia. Boulder: Lynne Rienner Publishers.

Mogahed, Dalia, and Azka Mahmood. 2019. American Muslim Poll 2019: Full Report. Dearborn: Institute for Social Policy and Understanding, Available online: https://www.ispu.org/american-muslim-poll-2019-full-report/ (accessed on 9 August 2020).

Morton, Rick. 2017. Australian Federation of Islamic Councils to repay $\$ 22$ million. The Australian. November 9. Available online: https://www.theaustralian.com.au/nation/education/australian-federation-of-islamiccouncils-to-repay-22-million/news-story/00e886d9c4d2d114bc8799c7df7d31ed (accessed on 21 July 2020).

Nikolayenko, Olena. 2008. Life Cycle, Generational and Period Effects on Protest Potential in Yeltsin's Russia. Canadian Journal of Political Science 41: 437-60. [CrossRef]

Pew Research Center. 2007. Muslim Americans: Middle Class and Mostly Mainstream. Washington: Pew Research Center, Available online: https://www.pewresearch.org/2007/05/22/muslim-americans-middle-class-andmostly-mainstream/ (accessed on 16 June 2020).

Pew Research Center. 2011. Muslim Americans: No Signs of Growth in Alienation or Support for Extremism. Washington: Pew Research Center, Available online: https://www.people-press.org/2011/08/30/muslim-americans-nosigns-of-growth-in-alienation-or-support-for-extremism/ (accessed on 16 June 2020).

Pew Research Center. 2012. The World's Muslims: Unity and Diversity. Washington: Pew Research Center, Available online: https://www.pewresearch.org/wp-content/uploads/sites/7/2012/08/the-worlds-muslims-full-report. pdf (accessed on 6 January 2020).

Pew Research Center. 2013. The World's Muslims: Religion, Politics and Society. Washington: Pew Research Center, Available online: https://www.pewforum.org/2013/04/30/the-worlds-muslims-religion-politicssociety-beliefs-about-sharia/ (accessed on 22 January 2020).

Pew Research Center. 2015. The Future of World Religions: Population Growth Projections, 2010-2050. Washington: Pew Research Center, Available online: https://www.pewforum.org/2015/04/02/religious-projections-2010-2050/ (accessed on 31 October 2019).

Pew Research Center. 2017. U.S. Muslims Concerned about Their Place in Society, but Continue to Believe in the American Dream. Washington: Pew Research Center, Available online: https://www.pewforum.org/2017/07/26/findingsfrom-pew-research-centers-2017-survey-of-us-muslims/ (accessed on 16 June 2020).

Rane, Halim. 2009. Reconstructing Jihad amid Competing International Norms. New York: Palgrave Macmillan.

Rane, Halim. 2019. Cogent Religious Instruction: A Response to the Phenomenon of Radical Islamist Terrorism in Australia. Religions 10: 246. [CrossRef]

Rane, Halim, and Sumra Salem. 2012. Social media, social movements and the diffusion of ideas in the Arab uprisings. Journal of International Communication 18: 97-111. [CrossRef]

Rane, Halim, Mahmood Nathie, Ben Isakhan, and Mohamad Abdalla. 2011. Towards understanding what Australia's Muslims really think. Journal of Sociology 47: 123-43. [CrossRef]

Rane, Halim, Jacqui Ewart, and John Martinkus. 2014. Media Framing of the Muslim World: Conflicts, Crises and Contexts. Berlin/Heidelberg: Springer.

Razek, Ali Abdel. 2013. Islam and the Foundations of Political Power. Edited by Abdou Filali-Ansary. Translated by Maryam Loutfi. Edinburgh: Edinburgh University Press.

Roy, Olivier. 1994. The Failure of Political Islam. Translated by Carol Volk. Cambridge: Harvard University Press.

Saeed, Abdullah. 2007. Trends in contemporary Islam: A preliminary attempt at a classification. The Muslim World 97: 395. [CrossRef]

Shavit, Uriya. 2014. Can Muslims Befriend Non-Muslims? Debating Al-Wala Wa-Al-Bara (Loyalty and Disavowal) in Theory and Practice. Islam and Christian-Muslim Relations 25: 67-88. [CrossRef]

Singer, Eleanor, Robert M. Groves, and Amy D. Corning. 1999. Differential incentives: Beliefs about practices, perceptions of equity, and effects on survey participation. The Public Opinion Quarterly 63: 251-60. [CrossRef]

Singer, Eleanor, John Van Hoewyk, and Mary P. Maher. 2000. Experiments with incentives in telephone surveys. Public Opinion Quarterly 64: 171-88. [CrossRef] 
Stoker, Gerry, Mark Evans, and Max Halupka. 2018. Democracy 2025: Trust and Democracy in Australia-Democratic Decline and Renewal; Parkes: Museum of Australian Democracy. Available online: https://www. democracy2025.gov.au/documents/Democracy2025-report1.pdf (accessed on 30 July 2020).

Wood, Asmi. 2013. Animal Welfare under the Shari'a. Macquarie Law Journal 12: 155-72.

(C) 2020 by the authors. Licensee MDPI, Basel, Switzerland. This article is an open access article distributed under the terms and conditions of the Creative Commons Attribution (CC BY) license (http://creativecommons.org/licenses/by/4.0/). 